\title{
SYMPATHO-ADRENAL RESPONSES DURING GENERAL ANAESTHESIA IN THE DOG AND MAN*†
}

\author{
R. A. Millar, M.D.(EDIN.), M.Sc., F.F.A.R.C.S., AND \\ M. E. MORRIS, M.D., C.M. $\ddagger$
}

THE ROLE of the sympathetic nervous system in the maintenance of circulatory homeostasis during general anaesthesia, some aspects of which have recently been reviewed, ${ }^{1}$ is both interesting and important, but remains to some extent enigmatic. During the past few years, with the aid of a chemical method which measures plasma adrenaline and noradrenaline with reasonable accuracy and sensitivity, we have studied the effects of haemorrhage, ${ }^{2,3}$ adrenergic blocking agents, ${ }^{4}$ apnoeic oxygenation,${ }^{5,6}$ and hypercarbia, ${ }^{7}$ organic buffering agents, ${ }^{8}$ and some aspects of general anaesthesia $;{ }^{9,10}$ clinically, measurements have been made in patients with adrenal medullary tumours ${ }^{11.12}$ and following circulatory occlusion during hypothermia. ${ }^{13}$ This paper is concerned with the documentation of plasma catecholamine levels, and with some attempts to interpret the sympathoadrenal activity which these represent, during general anaesthesia in the dog and man.

\section{Animal Experiments}

\section{Method}

In the majority of experiments, dogs (total number 56 , average weight approximately $10 \mathrm{~kg}$.) were lightly anaesthetized with minimal amounts of 2.5 per cent thiopental (usually less than $200 \mathrm{mg}$.), and the trachea was intubated with a no. 9 or 10 cuffed Magill tube. After injection of a few millilitres of 1 per cent lidocaine into the groin (to minimize the possibility of reflex effects from tissue trauma), a femoral artery was cannulated for removal of blood samples and recording of arterial pressure (Statham transducer Model P 23 A, Sanborn recorder). In several studies (see Results, Groups I and III), an intravenous infusion of succinylcholine $(0.1-0.2$ per cent) was then started, this being continued at a very slow rate during the subsequent period of inhalational anaesthesia. In all experiments, except those following adrenalectomy, Heparin, $2 \mathrm{mg} . / \mathrm{kg}$. was given intravenously. An equal volume of normal saline was injected intravascularly immediately following withdrawal of each blood sample.

The dogs in Group I were ventilated, in a semi-closed system, with an Emerson respirator modified for intermittent positive pressure ventilation $(10-15 \mathrm{~cm}$. $\mathrm{H}_{2} \mathrm{O}$ ) by the addition of an electrically-driven flanged wheel which "triggered" the respirator at a rate of about 15 per min. A Waters soda lime canister was

*Department of Anaesthesia, Montreal Neurological Institute, Queen Mary Veterans' Hospital, and McGill University, Montreal, P.Q.

†Awarded British Oxygen Canada Prize 1961.

$\ddagger$ Sir Edward W. Beatty Memorial Scholar.

Can. Anaes. Soc. J., vol. 8, no. 4, July, 1961 
interposed between respirator and endotracheal tube, the soda lime being changed at intervals of about $45 \mathrm{~min}$. The anaesthetics were delivered to the respirator from a Heidbrink apparatus with the "expiratory" side occluded and a Boyle "trichlorethylene" bottle connected in series with the "inspiratory" side. A constant flow of $3 \mathrm{~L}$. of oxygen per min. was used to vaporize halothane or chloroform which were placed in the Boyle bottle and maintained close to the 2-oz. mark. The concentrations of halothane and chloroform administered did not exceed 3 per cent. For the ether studies in Group I, the gas flow was increased to $5 \mathrm{~L}$. per min. and was bubbled through the Boyle "trichlorethylene" bottle filled with ether to the 4-oz. mark. Cyclopropane was administered in concentrations of 25-50 per cent in oxygen, at flow rates totalling $2 \mathrm{~L}$. per min.

Animals of Group II were anaesthetized with diethyl ether in a manner commonly employed for animal experimentation, the dogs being placed in a box into which a mixture of ether/air was blown. When surgical anaesthesia was reached the trachea was intubated and the aninals then inhaled from a $5-\mathrm{L}$. bag into which high flows of ether/air were delivered; a loose expiratory valve was used to keep resistance low and to prevent accumulation of carbon dioxide.

The intact and adrenalectomized animals in Group IIl were ventilated by means of a Bird respirator (Marks IV and VIII), using positive pressure only, with a Ruben non-rebreathing valve. Ether/oxygen was delivered to the respirator by way of an E.M.O. ether vaporizer, which for most studies was set to deliver 8 per cent ether. In four intact dogs in this group succinylcholine alone was used for endotracheal intubation.

The dogs in Group IV were also ventilated with a Bird respirator, connected to a Heidbrink closed circuit; $25-30$ per cent cyclopropane, in oxygen, was admintristered at total flow rates of $1,500 \mathrm{ml}$. per minute.

\section{Clinical Studies}

Fifty male patients, age range 21-64 years, were studied prior to and during a variety of surgical operations, excluding neurosurgery, thoracotomy, and all procedures carried out on patients not in the supine (or lithotomy) position. They were premedicated with atropine, 0.4-0.6 mg., and a brachial artery was cannulated with a Riley needle for removal of blood samples. For administration of ether anaesthesia a Boyle semi-closed anaesthetic apparatus was used, with a Fink or Ruben non-rebreathing valve. Following a brief induction period (nitrous oxide/oxygen), a flow of oxygen $10 \mathrm{~L}$. or higher was bubbled through the Boyle ether bottle, the ether level being maintained as close to the 10-oz. mark as possible. Nitrous oxide/oxygen/halothane was administered from a Boyle machine fitted with a "Fluotec" vaporizer (Mark I or II): halothane/oxygen was given by closed circuit using the technique described by Marrett. ${ }^{14}$ For cyclopropane oxygen anaesthesia a closed circuit Boyle apparatus was usually employed, with manual assistance to respiration; in some patients a Blease pulmoflator was used (positive pressure only), in conjunction with a Waters soda lime canister. All patients were intubated, with a no. 10 Magill cuffed endotracheal tube. 


\section{Laboratory Determinations}

Blood samples were withdrawn before and at various times during anaesthesia (see Results). For assay of plasma adrenaline and noradrenaline these comprised $35 \mathrm{ml}$., withdrawn into glass tubes moistened with a few drops of Heparin (Connaught Labs., 1,000 units/ml.), and centrifuged as soon as possible. The plasma was aspirated and applied to glass columns containing $500 \mathrm{mg}$. of alumina (Wöelm, non-alkaline Grade I; acid-washed in this laboratory). Adrenaline and noradrenaline in the plasma eluates were estimated fluorimetrically by the trihydroxyindole method, ${ }^{15}$ as described previously, ${ }^{4}$ but with the addition of $0.5 \mathrm{ml}$. of 1 per cent disodium ethylene diamine tetra-acetate to the final mixture before measurement of fluorescence. Errors of \pm 25 per cent are involved in the differential estimation of adrenaline and noradrenaline in single plasma samples and the values, which refer to $\mu \mathrm{g}$. free base/litre of plasma, are uncorrected for losses in recovery up to 30 per cent.

In most experiments, 8 - $\mathrm{ml}$. blood samples were withdrawn anaerobically into syringes moistened with heparin and containing a drop of mercury. Whole blood $\mathrm{pH}$, and the $\mathrm{pH}$ of separated plasna equilibrated at $38^{\circ} \mathrm{C}$ with known concentrations of $\mathrm{CO}_{2}$, were measured by means of Radiometer $\mathrm{pH}$ meters, Model 22 or Model 4, and the Astrup apparatus. ${ }^{16}$ From these $\mathrm{pH}$ determinations the "standard bicarbonate of separated plasma" and the $\mathrm{CO}_{2}$,tension were calculated as described by Astrup. ${ }^{17}$ In several most recent studies (dogs in Group IV; 12 patients anaesthetized with diethyl ether) microsamples of arterial blood were equilibrated with two $\mathrm{CO}_{2}$ tensions; ${ }^{18}$ the arterial $\mathrm{pCO}_{2}$ and "standard bicarbonate" of whole blood (at $\mathrm{pCO}_{2} 40 \mathrm{~mm}$. $\mathrm{Hg}$ ) were then determined from the appropriate $\log \mathrm{pCO}_{2} / \mathrm{pH}$ lines.

In certain studies (Groups I and II), arterial oxygeń saturation was determined spectrophotometrically. ${ }^{19}$ Blood ether concentrations (Groups I, II, and III ; 4 patients anaesthetized with diethyl ether) were estimated by a modification ${ }^{20}$ of the dichromate method. ${ }^{21}$ Whole blood glucose was measured (in adrenalectomized animals, Group III) according to Somogyi. ${ }^{22}$

\section{Statistical Methods}

Statistical analysis of the data was performed according to Snedecor ${ }^{23}$ and included analysis of variance, utilizing designed orthogonal comparisons and tests of all comparisons among means; the t-test as applied to paired values, modified where necessary to Cochran's approximation to the Behrens-Fisher test; and $r$, the coefficient of linear correlation.

\section{REsclts}

\section{Animal Experiments}

Group $I$. Table I presents the averaged data obtained in dogs before and. after ventilation for 90 minutes with oxygen and minimal amounts of diethyl ether, and from three other experimental groups anaesthetized with oxygen and halothane, cyclopropane, or chloroform. In these studies induction was with minimal thiopental and a slow intravenous infusion of succinylcholine $(0.2$ per cent) was given continuously. 
TABLE I

Average Results in Dogs of Group I Ventilated for 90 Minutes with Diethyl Eiher (7 Experiments), Halothane (5 Experiments), Cyclopropane (5 Experiments), and Chloroform ( 6 EXPERIMENTS)

\begin{tabular}{|c|c|c|c|c|c|c|}
\hline & $\mathrm{pH}$ & $\begin{array}{c}\mathrm{pCO}_{2} \\
(\mathrm{~mm} \cdot \mathrm{Hg})\end{array}$ & $\begin{array}{c}\text { Separated } \\
\text { plasma } \\
\text { standard } \\
\mathrm{HCO}^{-} \\
(\mathrm{mM} / \mathrm{L} .)\end{array}$ & $\begin{array}{c}\text { Adrenal- } \\
\text { ine } \\
(\mu \mathrm{g} . / \mathrm{L} .)\end{array}$ & $\begin{array}{c}\text { Noradrenal- } \\
\text { ine } \\
(\mu \mathrm{g} . / \mathrm{L} .)\end{array}$ & $\begin{array}{c}\text { Mean } \\
\text { arterial } \\
\text { blood } \\
\text { pressure } \\
(\mathrm{mm} . \mathrm{Hg})\end{array}$ \\
\hline $\begin{array}{c}\text { Diethyl Ether } \\
\text { Control } \\
+\mathbf{9 0}^{\prime}\end{array}$ & $\begin{array}{l}7.39 \\
7.32\end{array}$ & $\begin{array}{l}33 \\
35\end{array}$ & $\begin{array}{l}19 \\
18\end{array}$ & $\begin{array}{l}0.21 \\
0.81\end{array}$ & $\begin{array}{l}0.28 \\
0.50\end{array}$ & $\begin{array}{l}144 \\
124\end{array}$ \\
\hline $\begin{array}{l}\text { Halothane } \\
\text { Control } \\
+90^{\prime}\end{array}$ & $\begin{array}{l}7.30 \\
7.30\end{array}$ & $\begin{array}{l}47 \\
40\end{array}$ & $\begin{array}{l}22 \\
19\end{array}$ & $\begin{array}{l}0.48 \\
0.79\end{array}$ & $\begin{array}{l}0.19 \\
0.34\end{array}$ & $\begin{array}{r}146 \\
61\end{array}$ \\
\hline $\begin{array}{c}\text { Cyclopropane } \\
\text { Control } \\
+90^{\prime}\end{array}$ & $\begin{array}{l}7.40 \\
7.38\end{array}$ & $\begin{array}{l}37 \\
39\end{array}$ & $\begin{array}{l}21 \\
20\end{array}$ & $\begin{array}{l}0.34 \\
0.74\end{array}$ & $\begin{array}{l}0.22 \\
0.22\end{array}$ & $\begin{array}{l}143 \\
110\end{array}$ \\
\hline $\begin{array}{l}\text { Chloroform } \\
\text { Control } \\
+90^{\prime}\end{array}$ & $\begin{array}{l}7.36 \\
7.31\end{array}$ & $\begin{array}{l}41 \\
+7\end{array}$ & $\begin{array}{l}22 \\
21\end{array}$ & $\begin{array}{l}0.21 \\
0.89\end{array}$ & $\begin{array}{l}0.21 \\
0.65\end{array}$ & $\begin{array}{l}156 \\
104\end{array}$ \\
\hline
\end{tabular}

The values for arterial $\mathrm{pH}$ and $\mathrm{pCO}_{2}$ show that in general respiratory acidosis was avoided, although isolated $\mathrm{pCO}_{2}$ levels above $49 \mathrm{~mm}$. $\mathrm{Hg}$ were measured in two experiments with chloroform and in one study each with halothane and cyclopropane. Changes in "separated plasma' bicarbonate" demonstrate "metabolic" acid base alterations, but the levels are also influenced by respiratory acidosis or alkalosis. This fact, and the likelihood that blood loss involved in sampling may induce a mild metabolic acidosis, renders the assessment of small changes in the non-respiratory component of acid-base balance difficult in this group of experiments. It is well recognized that diethyl ether causes a metabolic acidosis in dogs, ${ }^{24}$ and this will be shown later in the present communication; the minor effect noted in the experiments tabulated in Table $\mathrm{I}$ is considered to be a result of light anaesthesia, the blood ether concentrations reaching an average maximum of only $100 \mathrm{mg} . / 100 \mathrm{ml}$. after 90 minutes of anaesthesia.

The average level of plasma adrenaline increased during anaesthesia with each of the four agents studied, but the rises were slight or moderate only, and the highest (average) levels did not exceed $1 \mu \mathrm{g} . / \mathrm{L}$. Changes in plasma noradrenaline were variable, although small increases were measured during ether and chloroform anaesthesia. From average control levels, of $0.49,0.67,0.56$, and $0.42 \mu \mathrm{g} . / \mathrm{L}$. respectively, total plasma catecholamine concentration (that is, adrenaline plus noradrenaline) increased to $1.3,1.1,0.96$, and $1.5 \mu \mathrm{g} . / \mathrm{L}$. after 90 minutes of ventilation with ether, halothane, cyclopropane, and chloroform respectively (Table I). Average mean arterial blood pressure was reduced by 14 per cent with diethyl ether, 58 per cent with halothane, 23 per cent with cyclopropane, and by 30 per cent with chloroform.

The results of the biochemical determinations performed on blood samples withdrawn after 15 and 45 minutes of anaesthesia have for the sake of brevity been excluded from Table I, but the plasma catecholamine levels measured at 
these times were taken into account in a statistical analysis of variance carried out on the data, shown in Table II. Under the specific conditions employed for

TABLE II

Analysis of Variance on the Data Obtained in Dogs Ventilated with Ether/Oxygen, Halothane, Crclopropane, and Chloroform (Group I)

\begin{tabular}{|c|c|c|c|c|}
\hline Source of variation & $\begin{array}{l}\text { Degrees of } \\
\text { freedom }\end{array}$ & $\begin{array}{l}\text { Adrenaline } \\
\text { mean square }\end{array}$ & $\begin{array}{l}\text { Noradrenaline } \\
\text { mean square }\end{array}$ & $\begin{array}{l}\text { Total amines } \\
\text { mean square }\end{array}$ \\
\hline $\begin{array}{l}\text { Diethyl Ether } \\
\text { Control vs. } 15^{\prime}, 45^{\prime}, 90^{\prime} \\
\text { Between dogs } \\
\text { Error }\end{array}$ & $\begin{array}{r}1 \\
6 \\
18\end{array}$ & $\begin{array}{l}1.0098^{*} \\
0.9622 \dagger \\
0.2219\end{array}$ & $\begin{array}{l}0.1475 \\
0.1972^{*} \\
0.0545\end{array}$ & $\begin{array}{l}1.9292^{*} \\
1.1222^{*} \\
0.3660\end{array}$ \\
\hline $\begin{array}{l}\text { Halothane } \\
\text { Control vs. } 15^{\prime}, 45^{\prime}, 90^{\prime} \\
\text { Between dogs } \\
\text { Error }\end{array}$ & $\begin{array}{r}1 \\
4 \\
12\end{array}$ & $\begin{array}{l}0.0836 \\
1.0355 \dagger \\
0.1186\end{array}$ & & $\begin{array}{l}0.1893 \\
1.5796 \dagger \\
0.0887\end{array}$ \\
\hline $\begin{array}{l}\text { Cyclopropane } \\
\text { Control vs. } 15^{\prime}, 45^{\prime}, 90 \\
\text { Between dogs } \\
\text { Error }\end{array}$ & $\begin{array}{lr}0^{\prime} & 1 \\
4 \\
12\end{array}$ & $\begin{array}{l}0.2344 \\
1.1800 \dagger \\
0.1041\end{array}$ & & $\begin{array}{l}0.1972 \\
1.1431 \dagger \\
0.1017\end{array}$ \\
\hline $\begin{array}{l}\text { Chloroform } \\
\text { Control vs. 15',45',90' } \\
\text { Between dogs } \\
\text { Error }\end{array}$ & $\begin{array}{r}1 \\
5 \\
15\end{array}$ & $\begin{array}{l}0.5117 \\
0.7584^{*} \\
0.1874\end{array}$ & $\begin{array}{l}0.2091 \\
0.0899 \\
0.0926\end{array}$ & $\begin{array}{l}1.3750^{*} \\
0.7541 \\
0.2963\end{array}$ \\
\hline
\end{tabular}

${ }^{*} p<0.05$

$\dagger p<0.01$

this group of studies, significant increases $(p<0.05)$ in total plasma catecholamine concentrations occurred only during anaesthesia with diethyl ether and chloroform; in the case of ether this was largely due to a significant rise in adrenaline $(p<0.05)$, while with chloroform both amines were involved. Changes in plasma adrenaline, noradrenaline, or total catecholamine concentration during halothane and cyclopropane anaesthesia were insignificant statistically. It should be noted that the marked variations "between dogs" in these experiments reflect a number of factors, among which are those caused by individual animal differences and those attributable to laboratory errors and variability.

Group II. The failure to detect more pronounced increases in plasma adrenaline and noradrenaline during ventilation with ether/oxygen was unexpected in view of previous work implicating diethyl ether as a sympatho-adrenal stimulant. ${ }^{25}$ The frequent use of this agent for animal experimentation and student teaching suggested a study of its effects when administered in a manner commonly used in pharmacology laboratories. Ether/air was therefore given to a second group of seven animals for periods of 180 minutes, initially by delivering the vapour into a box containing the $\operatorname{dog}$, thereafter by endotracheal insufflation. The results from these studies (in which thiopental and succinylcholine chloride were not used) are presented in Table III. The low average values for arterial $\mathrm{pH}$ and "separated plasma bicarbonate," becoming lower as anaesthesia continued, and the reduced arterial $\mathrm{pCO}_{2}$, illustrate the profound metabolic acidosis and respiratory stimulation which accompany moderately deep ether anaesthesia in dogs.

Control levels of plasma adrenaline and noradrenaline could not be determined 
TABLE III

Averaged Results ( 7 Experiments) in Dogs Breathing Ether/Air (Group II)

\begin{tabular}{|c|c|c|c|c|c|c|c|c|}
\hline & $\mathrm{pH}$ & $\begin{array}{c}\mathrm{pCO} \cdot \\
(\mathrm{nm} . \mathrm{Hg})\end{array}$ & $\begin{array}{c}\text { Separated } \\
\text { plasma } \\
\text { standard } \\
\mathrm{HCO}_{3}^{-} \\
\left(\mathrm{mM} / \mathrm{L}^{-} .\right)\end{array}$ & $\begin{array}{l}\text { Adrenal- } \\
\text { ine } \\
(\mu \mathrm{g} . / \mathrm{L} .)\end{array}$ & $\begin{array}{c}\text { Noradrenal- } \\
\text { ine } \\
(\mu \mathrm{g} . / \mathrm{L} .)\end{array}$ & $\begin{array}{c}\text { Mean } \\
\text { arterial } \\
\text { - blood } \\
\text { pressure } \\
(\mathrm{mm} . \mathrm{Hg})\end{array}$ & $\begin{array}{c}\text { Blood } \\
\text { ether } \\
\text { (mg./100 } \\
\text { ml.) }\end{array}$ & $\begin{array}{c}\text { Oxygen } \\
\text { saturation } \\
\text { (Percentage) }\end{array}$ \\
\hline$+45^{\prime}$ & 7.25 & 28 & 12.6 & 1.6 & 0.72 & 124 & 130 & 88 \\
\hline$+75^{\prime}$ & 7.20 & 28 & 11.1 & 2.0 & 1.5 & 115 & 127 & .93 \\
\hline$+135^{\prime}$ & 7.16 & 27 & 99 & 2.6 & 1.1 & 118 & 121 & 93 \\
\hline$+180^{\prime}$ & 7.11 & 29 & 95 & 2.2 & 1.5 & 112 & 143 & 96 \\
\hline
\end{tabular}

in these animals before induction of anaesthesia, but the subsequent concentrations during ether/air anaesthesia were obviously greatly increased over any measured in samples withdrawn from apparently norrnal conscious humans (see later in this communication), or from dogs very lightly anaesthetized with thiopental in numerous studies carried out in this laboratory..$^{2-10}$ During aperiod extending from 45 to 180 minutes after induction, average plasma adrenaline varied from 1.6 to $2.6 \mu \mathrm{g}$./L. and plasma noradrenaline from 0.72 to $1.5 \mu \mathrm{g} . / \mathrm{L}$., in these animals breathing ether/air.

The average plasma adrenaline and noradrenaline concentrations measured in this group of animals after 45 minutes of ether/air anaesthesia (Table III) were significantly higher $(p<0.05)$ than the adrenaline and noradrenaline levels $(0.52$ and $0.26 \mu \mathrm{g} . / \mathrm{L}$. respectively), in the dog's ventilated for the same period with ether/oxygen (Group I). It was considered that several obvious factors could have been partly responsible for the difference - struggling during induction with ether/air; a primary or secondary effect of the metabolic acidosis which was more pronounced in the ether/air group; and the possibility that the use of minimal thiopental and succinylcholine might "dampen down" sympathetic activity during anaesthesia with ether/oxygen, although neither drug had previously interfered with the measurement of increased plasma catecholamine levels in dogs subjected to a variety of stimuli (and in fact did not retard increases in plasma adrenaline in response to haemorrhage during ether/oxygen anaesthesia, as will be shown later). Other differences were that one group of animals was breathing spontaneously while the other was being ventilated artificially; and that arterial oxygen saturation, which was consistently 98-100 per cent during anaesthesia with ether/oxygen, averaged only 88 per cent after 45 minutes of ether/air (although it increased progressively thereafter). Finally, the factor considered to be of major significance was the difference in blood ether concentrations, which averaged $130 \mathrm{mg} . / 100 \mathrm{ml}$. after 45 minutes of ether/air and only $84 \mathrm{mg} .100 \mathrm{ml}$. after the same period of ether/oxygen.

Group III. The number of discrepancies between the first two experimental groups underlined the need for further studies: Table IV presents the averaged data obtained from six experiments in which dogs were ventilated for two hours with ether/oxygen under reasonably steady state conditions. Preliminary endotracheal intubation was performed in two animals under light thiopental anaesthesia, and in the other four experiments with the aid of intravenous succinylcholine alone, this subsequently being given as an infusion throughout every 
TABLE IV

Averaged Resulas (6 Experiments) in Dogs Ventilated with Ether/Oxygen for Two Hours (GROUP III)

\begin{tabular}{|c|c|c|c|c|c|c|c|c|}
\hline & $\mathrm{pH}$ & $\begin{array}{c}\mathrm{pCO}_{2} \\
(\mathrm{~mm} . \mathrm{Hg})\end{array}$ & $\begin{array}{c}\text { Separated } \\
\text { plasma } \\
\text { standard } \\
\mathrm{HCO}_{3}^{-} \\
(\mathrm{mm} . / \mathrm{L} .)\end{array}$ & $\begin{array}{l}\text { Adrenal- } \\
\text { ine } \\
(\mu \mathrm{g} . / \mathrm{L} .)\end{array}$ & $\begin{array}{c}\text { Noradrenal- } \\
\text { ine } \\
(\mu \mathrm{g} . / \mathrm{L} .)\end{array}$ & $\begin{array}{c}\text { Blood } \\
\text { ether } \\
\text { (mg./100 } \\
\text { ml.) }\end{array}$ & $\begin{array}{c}\text { Mean } \\
\text { arterial } \\
\text { blood } \\
\text { pressure } \\
(\mathrm{mm} . \mathrm{Hg})\end{array}$ & $\begin{array}{l}\text { Heart } \\
\text { rate }\end{array}$ \\
\hline $\begin{array}{l}-\overline{3} \\
+30^{\prime} \\
+60^{\prime} \\
+90^{\prime} \\
+120^{\prime}\end{array}$ & $\begin{array}{l}7.48 \\
7.37 \\
7.33 \\
7.27 \\
7.23\end{array}$ & $\begin{array}{l}27 \\
31 \\
30 \\
33 \\
33\end{array}$ & $\begin{array}{ll}19 & 2 \\
17 & 2 \\
15 & 6 \\
15 & 0 \\
13 & 8\end{array}$ & $\begin{array}{ll}0 & 12 \\
0.52 \\
0 & 93 \\
1.0 \\
1.7\end{array}$ & $\begin{array}{l}0.22 \\
0.44 \\
0.58 \\
0.89 \\
1.1\end{array}$ & $\begin{array}{l}143 \\
154 \\
152 \\
153\end{array}$ & $\begin{array}{l}133 \\
120 \\
102 \\
105 \\
103\end{array}$ & $\begin{array}{r}99 \\
179 \\
169 \\
155 \\
162\end{array}$ \\
\hline
\end{tabular}

study. The results demonstrate progressive rises in average plasma adrenaline and noradrenaline, a fall in $\mathrm{pH}$ and "separated plasma bicarbonate" attributable to a non-respiratory acidosis, an increase in heart rate, and a gradual reduction in arterial blood pressure. Table $\mathrm{V}$ shows the relevant statistical analysis of

TABLE V

Analysis of Variance on the Results Obtainfd during Ventilation with Ether/Oxygen in the Intact and Adrenalectomizrd Dogs of Group III

\begin{tabular}{|c|c|c|c|c|c|}
\hline \multirow[b]{2}{*}{ Source of variation } & \multirow[b]{2}{*}{$\begin{array}{l}\text { Degrees } \\
\text { of } \\
\text { freedom }\end{array}$} & \multicolumn{2}{|c|}{ Intact } & \multicolumn{2}{|c|}{ Adrenalectomized } \\
\hline & & $\begin{array}{l}\text { Adrenaline } \\
\text { mean } \\
\text { square }\end{array}$ & $\begin{array}{c}\text { Noradrenaline } \\
\text { mean } \\
\text { square }\end{array}$ & $\begin{array}{l}\text { Adrenaline } \\
\text { mean } \\
\text { square }\end{array}$ & $\begin{array}{l}\text { Noradrenaline } \\
\text { mean } \\
\text { square }\end{array}$ \\
\hline $\begin{array}{l}\text { Control vs. } 30^{\prime}, 60^{\prime}, 90^{\prime}, 120^{\prime} \\
\text { Among samples during }\end{array}$ & 1 & $42300^{*}$ & $1.2793 \dagger$ & 00042 & 02623 \\
\hline $\begin{array}{l}\quad \text { anaesthesia } \\
\text { Between dogs } \\
\text { Error }\end{array}$ & $\begin{array}{r}3 \\
5 \\
20\end{array}$ & $\begin{array}{ll}1 & 4746 \\
3 & 3684 \dagger \\
0 & 8032\end{array}$ & $\begin{array}{ll}0 & 4674 \uparrow \\
0 & 1310 \\
0 & 0917\end{array}$ & $\begin{array}{ll}0 & 0447 \\
0 & 0160 \\
0 & 0298\end{array}$ & $\begin{array}{ll}0 & 1077 \\
0 & 1872 \\
0 & 1052\end{array}$ \\
\hline
\end{tabular}

${ }^{*} p<0 \quad 05$

$\dagger p<001$

variance on the catecholamine data (intact dogs). Plasma noradrenaline showed highly significant increases over control samples at all times after 30 minutes of ether anaesthesia $(p<0.01)$, while a greater variability in adrenaline response is shown by the fact that increases were significant statistically only when the control samples were compared with those after two hours of ether anaesthesia $(p<0.05)$.

In this group of intact animals (Table IV) a direct and significant relationship $(p<0.01)$ could be shown between total catecholamine and blood ether concentrations (Fig. 1). Figure 2, from one experiment, illustrates the effects on arterial $\mathrm{pH}$, plasma catecholamines, and mean arterial blood pressure, of ventilation with ether/oxygen to blood levels of ether which are at the upper limit of, and above, the clinical range.

Comparison of the results given in Tables III and IV shows that the metabolic acidosis accompanying spontaneous breathing of ether/air was more severe than that induced by ventilation with ether/oxygen, at roughly comparable times, even though blood ether levels were higher in the latter group. A lower arterial oxygen saturation may be partly responsible for this, and for the somewhat 


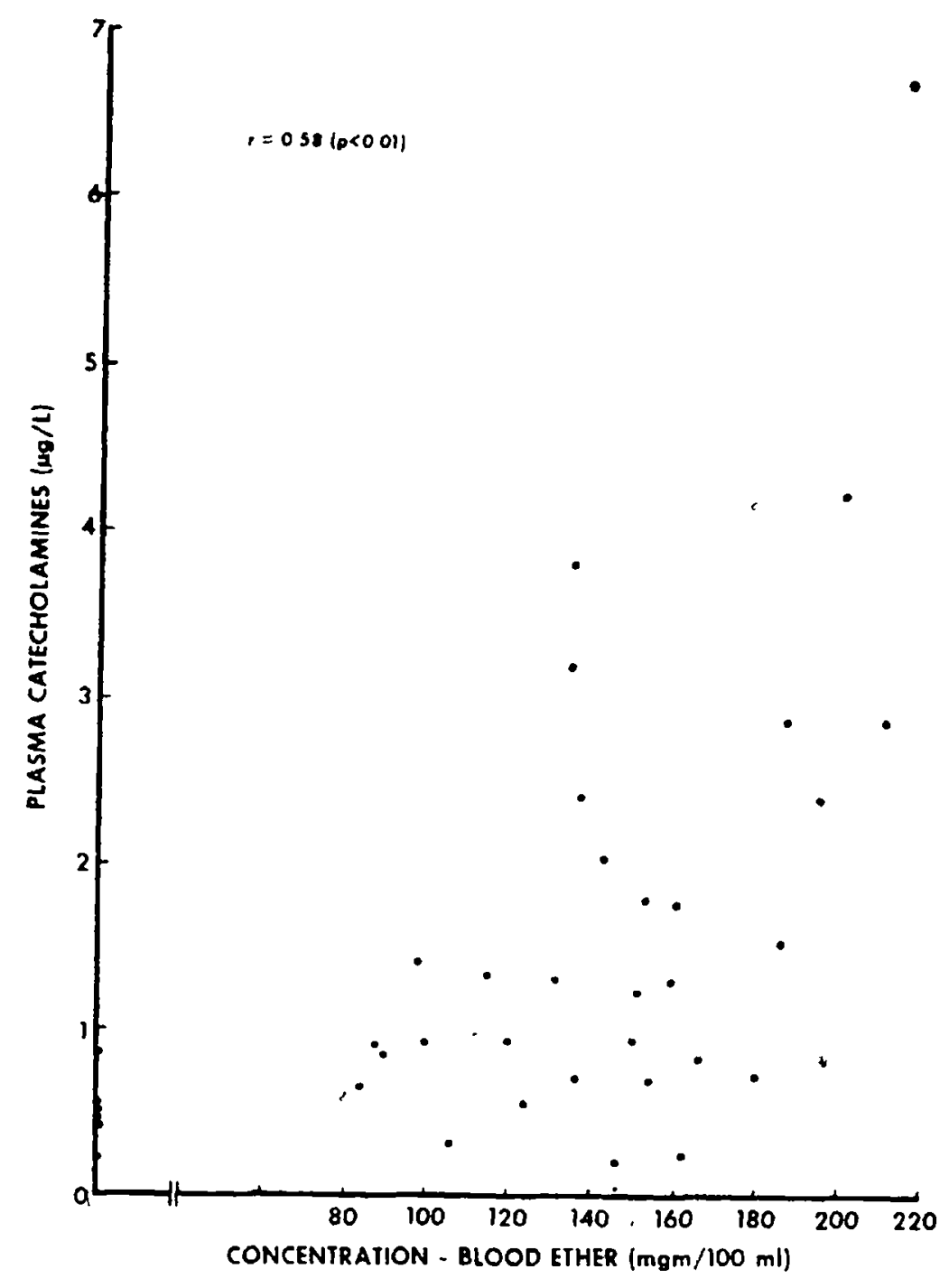

FigURE 1. Relation between total plasma catecholamines and blood ether concentrations during ether anaesthesia in six intact dogs (Group III).

higher plasma catecholamine levels in the ether/air group, but the differences may also be related to increased muscular activity involved in the spontaneous response of this group of animals to an increased "respiratory drive" induced by diethyl ether.

Figure 3, from the data obtained in the ether/oxygen group of dogs (average results in Table IV), illustrates the highly significant $(p<0.001)$ inverse correlation between the levels of plasma adrenaline and "separated plasma bicarbonate"; this confirms a relationship previously suggested by Brewster and colleagues. ${ }^{26}$

In an attempt to identify the source of the noradrenaline liberated in the dog during ether anaesthesia, six animals were adrenalectomized bilaterally and after a rest period of about 45 minutes were ventilated with ether/oxygen for two hours. The results are shown in Table VI. Average blood ether levels at each time interval were lower than in the comparable group of intact dogs (see Table IV), which to some extent affects close comparisons of the two groups. As was expected following adrenalectomy, plasma adrenaline failed to increase during ether anaesthesia. Plasma noradrenaline showed small or moderate rises, but because of variability the response was insignificant statistically. Figure $4 \mathrm{com}$ pares the adrenaline and noradrenaline levels in the intact and adrenalectomized 

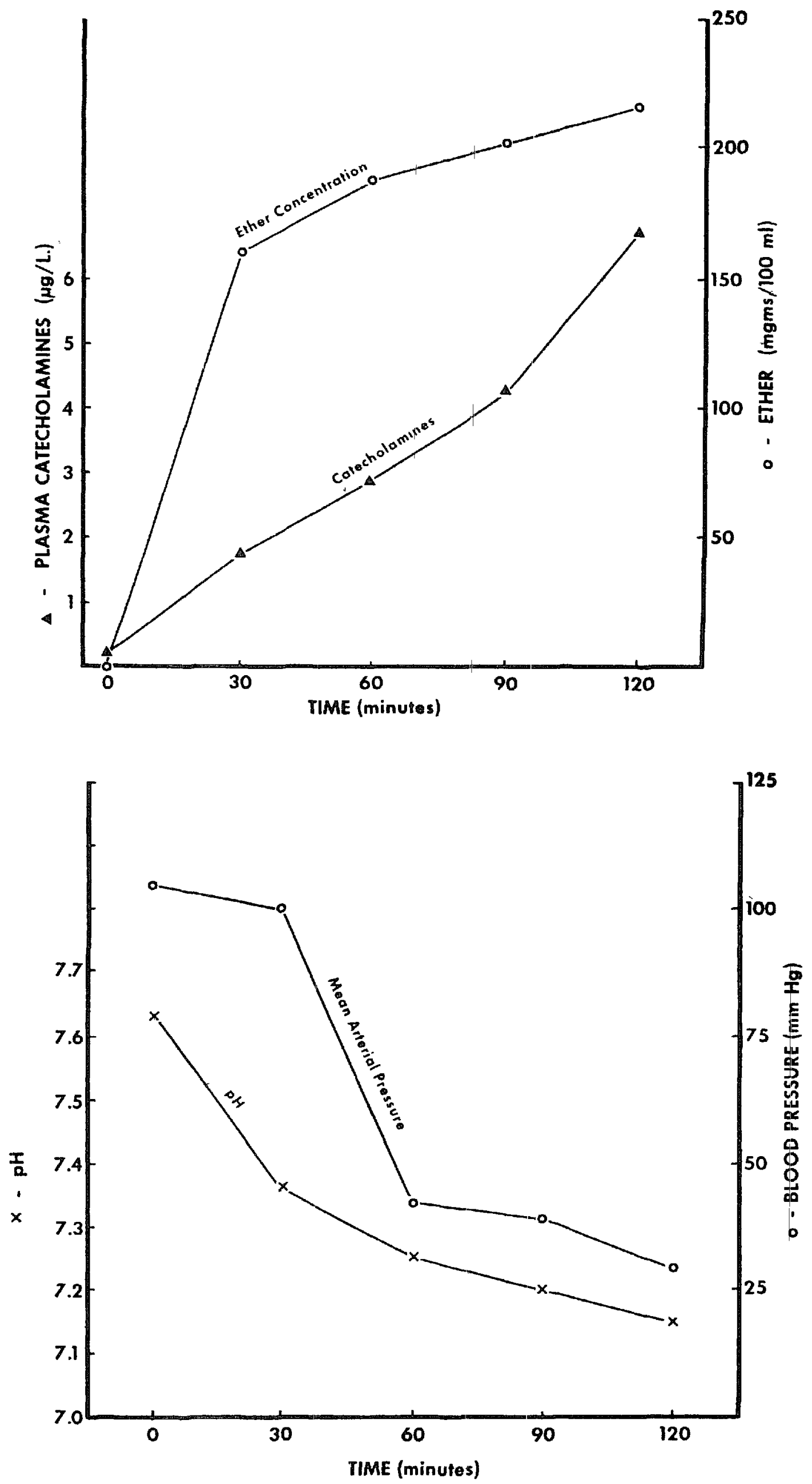

FIGURE 2. Arterial pH, total plasma catecholamines, blood ether concenttrations, and mean arterial blood pressure changes in one animal study during ether/oxygen ventilation (Group III). 


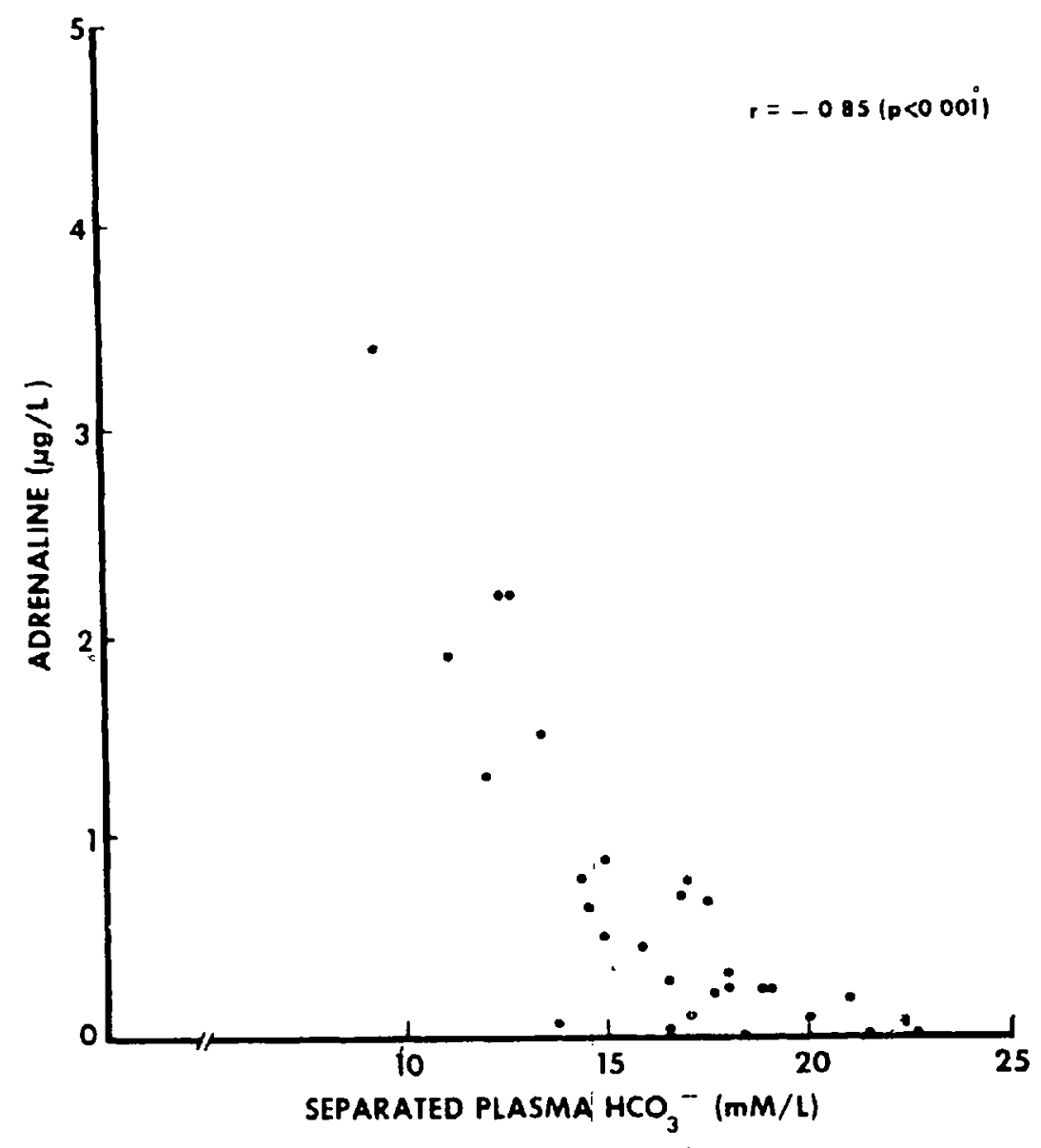

FIGÚRE 3. Relation between plasma adrenaline and "separated plasma standard bicarbonate" during ether/ oxygen ventilation of intact dogs (Group III).

TABLE VI

Average Results in Adrenalectomized Dogs (6 Experiments) Ventilated with Ether/ OXYGEN (GROUP III)

\begin{tabular}{|c|c|c|c|c|c|c|c|c|c|}
\hline & $\mathrm{pH}$ & $\begin{array}{l}\mathrm{pCO}_{2} \\
\underset{\mathrm{mm}}{\mathrm{mg}} .\end{array}$ & $\begin{array}{c}\text { Separated } \\
\text { plasnia } \\
\text { standard } \\
\mathrm{HCO}_{3}^{-} \\
(\mathrm{mM} . / \mathrm{L} .)\end{array}$ & $\begin{array}{l}\text { Adren- } \\
\text { aline } \\
(\mu \mathrm{g} . / \mathrm{L} .)\end{array}$ & 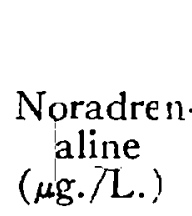 & $\begin{array}{c}\text { Mean } \\
\text { arterial } \\
\text { - blood } \\
\text { pressure } \\
\text { (mm. Hg) }\end{array}$ & $\begin{array}{l}\text { Heart } \\
\text { rate }\end{array}$ & $\begin{array}{c}\text { Blood } \\
\text { glucose } \\
\text { (mg./ } \\
100 \mathrm{ml} .)\end{array}$ & $\begin{array}{l}\text { Blood } \\
\text { ether } \\
\text { (mg./ } \\
100 \mathrm{ml} \text {.) }\end{array}$ \\
\hline $\begin{array}{l}-\overline{3} \\
+30^{\prime} \\
+60^{\prime} \\
+90^{\prime} \\
+120^{\prime} \\
20 \% \mathrm{CO}_{2}\end{array}$ & $\begin{array}{l}7.48 \\
7.46 \\
7.41 \\
7.40 \\
7.37 \\
6.79\end{array}$ & $\begin{array}{r}24 \\
26 \\
28 \\
28 \\
28 \\
160\end{array}$ & $\begin{array}{l}18 \\
18 \\
17 \\
17 \\
16 \\
19\end{array}$ & $\begin{array}{l}0.10 \\
0.04 \\
0.21 \\
0.08 \\
0.20 \\
042\end{array}$ & $\begin{array}{l}0.25 \\
0.36 \\
0.48 \\
0.41 \\
0.67 \\
1.6\end{array}$ & $\begin{array}{r}121 \\
109 \\
104 \\
88 \\
86 \\
51\end{array}$ & $\begin{array}{l}165 \\
174 \\
160 \\
159 \\
170 \\
168\end{array}$ & $\begin{array}{l}74 \\
75 \\
74 \\
74 \\
67 \\
89\end{array}$ & $\begin{array}{l}-113 \\
128 \\
137 \\
135 \\
151\end{array}$ \\
\hline
\end{tabular}

animals ventillated with ether/oxygen--the $\mathrm{pCO}_{2}$ levels were very similar, as shown in Tables IV and VI. In the dog anaesthetized with diethyl ether release of noradrenaline occurs partly from extra-adienal areas. Because blood ether levels were lower in the adrenalectomized animals, it is possible that at equivalent anaesthetic concentrations extra-adrenal release of noradrenaline would be proportionately"greater than is shown in Figure 4.

Following this two-hour period of ventilation with ether/oxygen in adrenal-1 

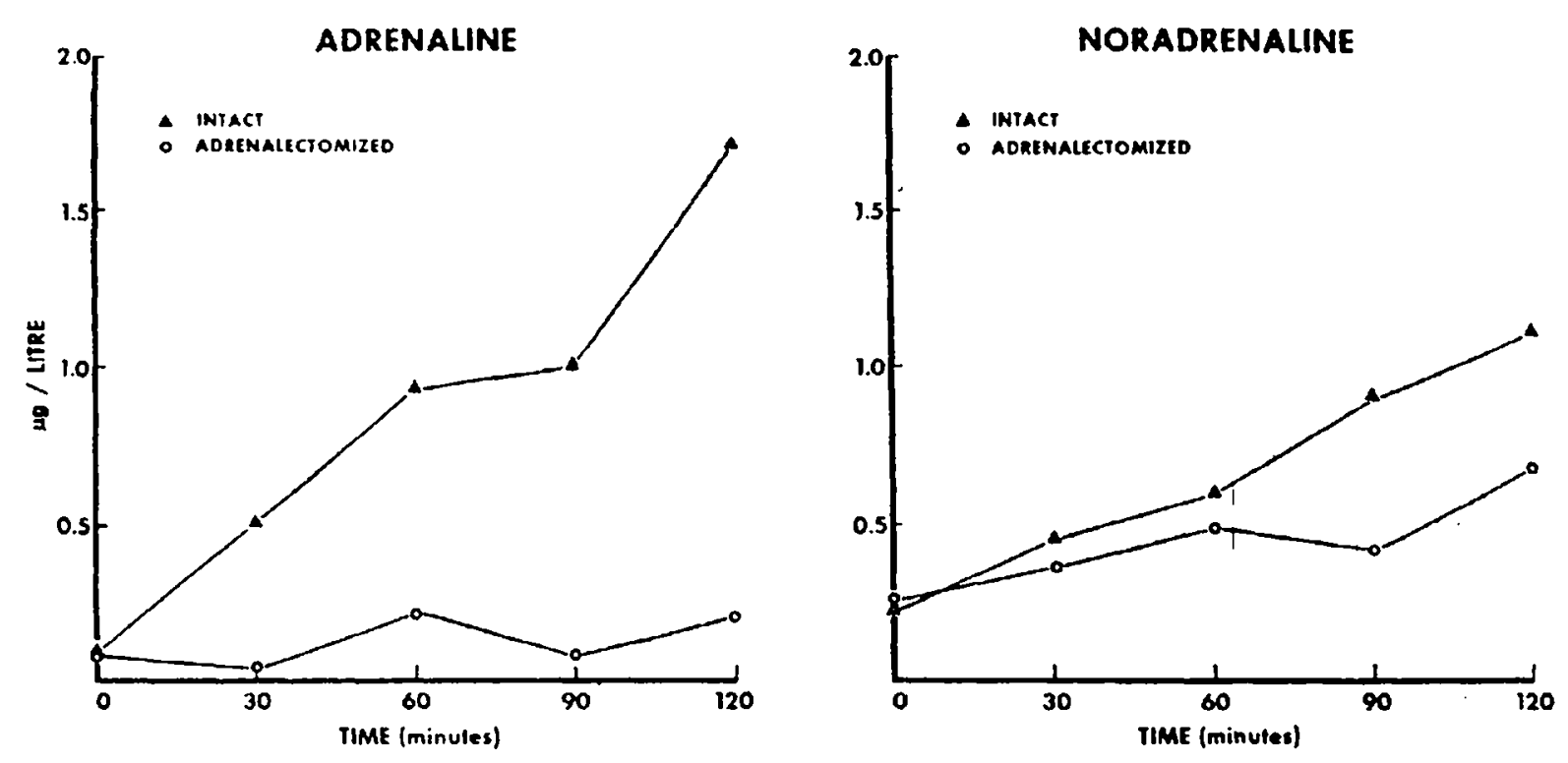

Figure 4. Average values of plasma adrenaline and noradrenaline during ether/ oxygen ventilation in six intact dogs and six adrenalectomized dogs (Group III).

ectomized dogs, hypercarbia was induced with 18 per cent carbon dioxide/oxygen /ether. The immediate circulatory response to carbon dioxide was usually a fall in mean arterial and pulse pressures; systolic pressure then increased, but fell gradually over the next few minutes. Blood samples were withdrawn after 8 to 14 minutes (average $10 \mathrm{~min}$. ), at which times systolic and diastolic pressures were both reduced, while plasma noradrenaline was increased to levels significantly higher $(p<0.05)$ than those induced by ether anaesthesia alone (Table VI). The further increase in blood ether concentration (average $16 \mathrm{mg} . / 100 \mathrm{ml}$.) resulting from this 10 -minute period of hypercarbia should be noted, since this might explain in part a further increase in plasma noradrenaline concentration. However, no significant correlation could be established between total catecholamine and blood ether levels during the preceding two hours of ether anaesthesia (in the adrenalectomized animals, see Table XIII). Furthermore, at almost identical average blood ether concentrations plasma noradrenaline was higher during hypercarbia in adrenalectomized dogs than at normal $\mathrm{pCO}_{2}$ in the intact animals. Thus, it is considered that the increases in plasma noradrenaline as a result of ventilation with carbon dioxide were too great to be affected, except to a minor degree, by the relatively small increase in blood ether concentration.

Comparison of the acid-base data in Table IV (intact) and Table VI (adrenalectomized) shows that adrenalectomy greatly reduced the metabolic acidosis induced by ether anaesthesia in the dog. This can be further demonstrated by $\mathrm{pCO}_{2} / \mathrm{pH}$ plots (semi-logarithmic scale) for blood samples withdrawn before and after two hours of ether anaesthesia (Fig. 5). In intact dogs the points for samples withdrawn at the end of this period of anaesthesia lie to the left (acid side) of those for control samples. Since the "control" and "anaesthesia" $\mathrm{pCO}_{2}$ levels did not differ significantly, this indicates the existence of a metabolic acidosis after two hours of ether anaesthesia. In the adrenalectomized animals the difference is much smaller. A comparison of the changes in "separated plasma bicarbonate" before and after two hours of ether anaesthesia in intact and adrenalectomized animals shows a significantly more marked $(p<0.05)$ metabolic 


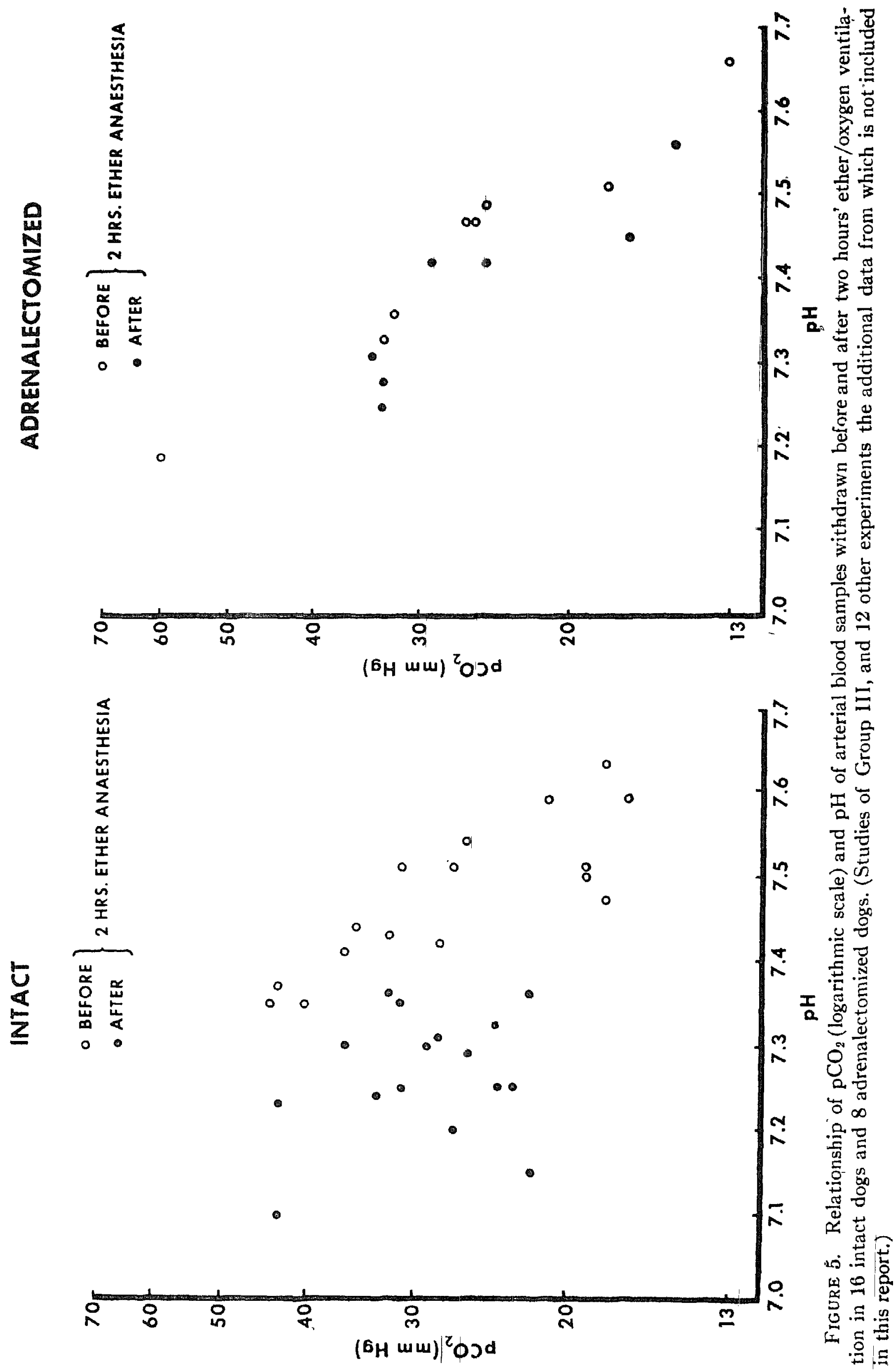




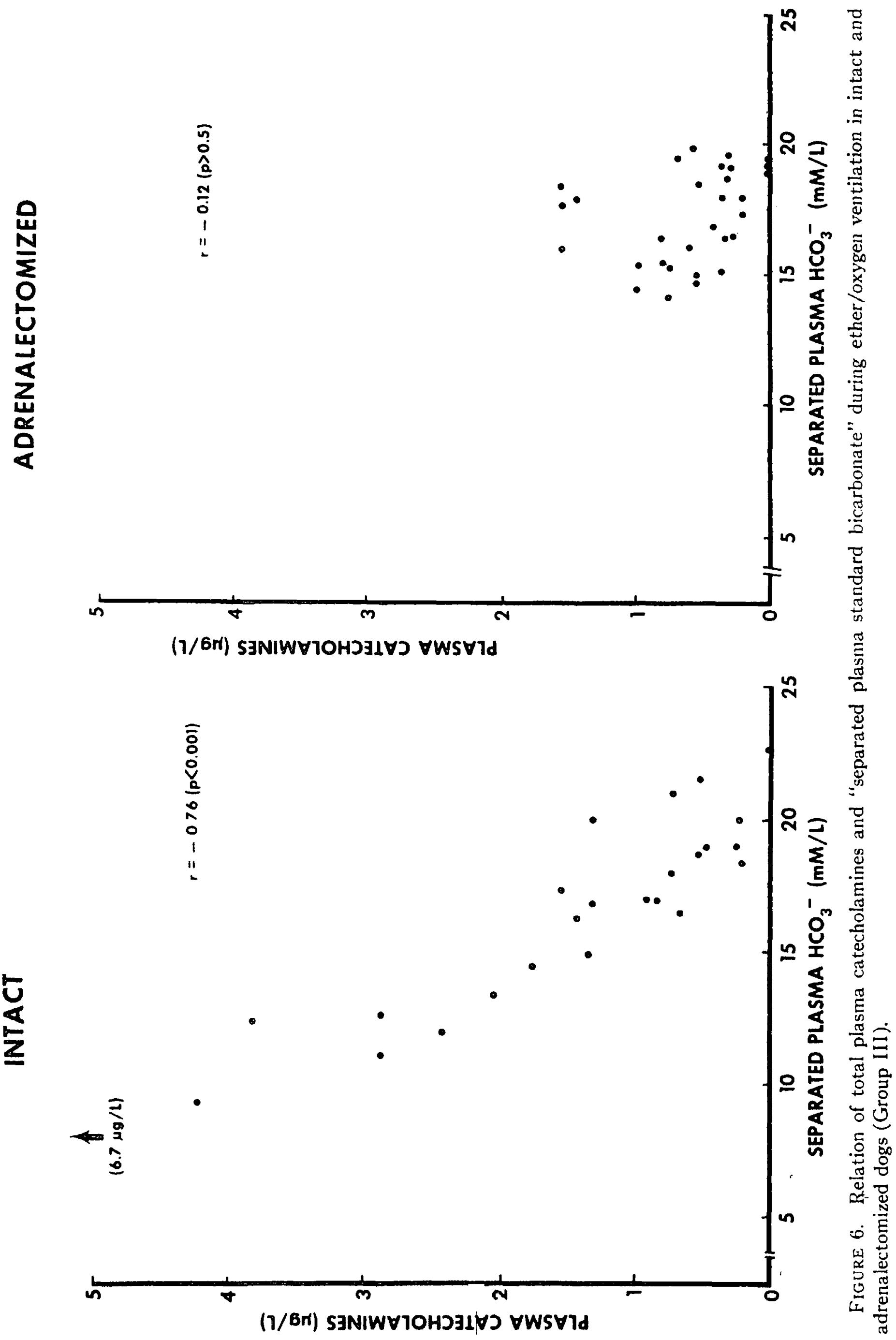


acidosis in the intact animals. Figure 6 contrasts the relationship between total catecholamine concentration and "separated plasma bicarbonate" in the intact with that in the adrenalectomized dogs anaesthetized with ether; in the intact group a highly significant inverse correlation $(p<0.01)$ could be demonstrated, but mot in the adrenalectomized animals. Blood sugar levels in the adrenalectomized dogs showed little or no change during ether anaesthesia at normal $\mathrm{pCO}_{2}$ (Table VI), by comparison with the increases known to occur in intact animals. ${ }^{27}$

Control blood pressures and heart rate were respectively lower and higher in the adrenalectomized than in the intact dogs, but the difference in the degree of change induced by ether in the two groups was less than expected. Thus, in the intact animals mean arterial bood pressure after two hours of ether anaesthesia (average blood ether concentration $153 \mathrm{mg} . / 100 \mathrm{ml}$.) was reduced by 23 per cent of the control value, while in the adrenalectomized dogs (average blood ether $135 \mathrm{mg} . / 100 \mathrm{ml}$.) the reduction was by 29 per cent of control. This indicates that serious circulatory impairment is not a necessary accompaniment of moderately deep ether anaesthesia in adrenalectomized dogs. Percentage changes in mean arterial blood pressure in the adrenalectomized dogs show a highly significant negative correlation $(r=-0.701$, Table XIII) with blood ether concentrations, during two hours of anaesthesia. A similar analysis in the intact dogs of the same group shows that for blood ether levels below $180 \mathrm{mg} . / 100 \mathrm{ml}$. there is no correlation of significance $(r=0.143)$; when the seven values above this level are included correlation becomes more definite $(r=-0.565)$, from which it can probably be inferred that at very high blood ether concentrations release of catecholamines from the adrenal medulla does not antagonize the circulatory depressant action of diethyl ether.

Group IV. As was shown in Table I, and contrary to studies in man by other workers ${ }^{28,29}$ cyclopropane anaesthesia in dogs was not associated with convincing increases in plasma noradrenaline. This was reinvestigated and confirmed at a later date in a group of six dogs ventilated for 90 minutes with $25-30$ per cent cyclopropane in oxygen (induction with minimal thiopental, no succinylcholine used). Small, statistically significant rises in plasma adrenaline were measured (Table VII), similar to those in the earlier group (Table I); this degree of increase

TABLE VII

Average Results (6 Studies, Group IV) of Ventilation with 25-30 Per Cent Cyclopropane in OXYGen, AND a Further 20 Minutes of Hypercarbia

\begin{tabular}{cccccccc}
\hline \hline & & $\begin{array}{c}\text { Standard } \\
\text { HCO } \\
\text { (whole } \\
\text { blood) }\end{array}$ & $\begin{array}{c}\text { Mean } \\
\text { Adrenaline } \\
(\mu g . / \mathrm{L} .)\end{array}$ & $\begin{array}{c}\text { Noradrenaline } \\
(\mu g . / \mathrm{L} .)\end{array}$ & $\begin{array}{c}\text { arterial } \\
\text { blood } \\
\text { (mm Hg })\end{array}$ & $\begin{array}{c}\text { Heart } \\
\text { rate }\end{array}$ \\
\hline Control & 7.494 & 24 & 21.3 & 0.05 & 0.18 & 110 & 102 \\
$+15^{\prime}$ & 7.542 & 21 & 21.0 & 0.17 & 0.23 & 102 & 97 \\
$+45^{\prime}$ & 7.519 & 22 & 20.4 & 0.25 & 0.21 & 116 & 104 \\
$+90^{\prime}$ & 7.487 & 22 & 19.3 & 0.36 & 0.19 & 108 & 100 \\
$15 \% \mathrm{CO}_{2}$ & 6.949 & 108 & 146 & 1.7 & 1.1 & 88 & 140 \\
\hline
\end{tabular}

is difficult to assess when considered with the small reduction in "whole blood standard-bicarbonate," since both these effects could be a result of blood sampling 
in these dogs, whose mean weight of only $7 \mathrm{~kg}$. was well below the average for this laboratory. No significant changes in plasma noradrenaline were measured during cyclopropane anaesthesia.

It is emphasized that the "whole blood standard bicarbonate" determined in this group of experiments ${ }^{30}$ is not necessarily influenced by changes in arterial $\mathrm{pCO}_{2}$, the values representing the metabolic component of acid-base balance.

After 90 minutes of $25-30$ per cent cyclopropane anaesthesia, heart rate and mean arterial pressure were almost unchanged from control values, although systolic pressure was reduced and diastolic increased.

When hypercarbia was induced by ventilation with 15 per cent carbon dioxide and 25 per cent cyclopropane in oxygen for 20 minutes, plasma adrenaline and noradrenaline both showed marked increases (Table VII). The average increase and the variability were both greater in the case of adrenaline, and the changes were not significant statistically. By comparison with the levels after 90 minutes of anaesthesia with "normal" $\mathrm{pCO}_{2}$, noradrenaline was significantly increased after this 20 -min. period of hypercarbia during cyclopropane anaesthesia ( $p$ $<0.05)$. The initial circulatory response to carbon dioxide was usually a fall in pulse and mean pressures, this being followed by a phase of increased systolic and lowered diastolic pressures. Heart rate was increased. After 20 minutes mean pressure was reduced, largely because of the reduced diastolic pressure.

The pronounced reduction in "whole blood standard bicarbonate," at an average $\mathrm{pCO}_{2}$ of $108 \mathrm{~mm}$. $\mathrm{Hg}$, demonstrates that a metabolic acidosis was induced by hypercarbia during cyclopropane anaesthesia.

\section{Other Observations on Haemorrhage, Hypercarbia, and Asphyxia}

In a previous study it was shown that increases in plasma catecholamine levels in response to haemorrhagic hypotension and hypercarbia were not prevented during anaesthesia with oxygen and halothane ( 2 per cent or higher). ${ }^{9}$ In the present studies, five dogs (from Group I) were subjected to a $20 \mathrm{ml} . / \mathrm{kg}$. haemorrhage during ventilation with ether/oxygen (blood levels averaging $100 \mathrm{mg}$./ $100 \mathrm{ml}$.). The data in Table VIII show that plasma adrenaline increased markedly in every instance, with minimal changes in noradrenaline. There is clearly no

TABLE VIII

Plasma Adrenaline and Noradrenaline Levels before and after Haemorrhage (Approximately. 20 Ml./Kg.) in 5 Dogs Ventilated with Ether/Oxygen (Group I)

\begin{tabular}{|c|c|c|c|c|c|}
\hline \multicolumn{3}{|c|}{ Before haemorrhage } & \multicolumn{3}{|c|}{ After haemorrhage } \\
\hline $\begin{array}{c}\text { Mean } \\
\text { arterial } \\
\text { blood } \\
\text { pressure } \\
\text { (mm. Hg) }\end{array}$ & $\begin{array}{l}\text { Adrenaline } \\
(\mu \mathrm{g} . / \mathrm{L} .)\end{array}$ & $\begin{array}{c}\text { Noradrenaline } \\
(\mu \mathrm{g} . / \mathrm{L} .)\end{array}$ & $\begin{array}{c}\text { Mean } \\
\text { arterial } \\
\text { blood } \\
\text { pressure } \\
\text { (mm. Hg) }\end{array}$ & $\begin{array}{l}\text { Adrenaline } \\
(\mu \mathrm{g} . / \mathrm{L} .)\end{array}$ & $\begin{array}{l}\text { Noradrenaline } \\
(\mu \mathrm{g} . / \mathrm{L} .)\end{array}$ \\
\hline $\begin{array}{l}119 \\
127 \\
163 \\
115 \\
128\end{array}$ & $\begin{array}{ll}0.37 \\
0.60 \\
1.2 \\
0 & 56 \\
0 & 99\end{array}$ & $\begin{array}{l}0.18 \\
0.12 \\
0.36 \\
0.95 \\
0.23\end{array}$ & $\begin{array}{l}83 \\
65 \\
60 \\
33 \\
90\end{array}$ & $\begin{array}{l}1.6 \\
2.2 \\
7.6 \\
5.9 \\
3.5\end{array}$ & $\begin{array}{ll}0 & 26 \\
0 . & 36 \\
0 & 84 \\
1.0 \\
0 & 32\end{array}$ \\
\hline 130 & 074 & 0.37 & 66 & 4.2 & 056 \\
\hline
\end{tabular}


evidence that diethyl ether impairs the sympatho-adrenal responses to haemorrhage; comparison with the values previously measured during light thiopental anaesthesia ${ }^{2}$ could even favour an enhanced response during ether anaesthesiai (although this could not be accepted without further studies). As shown earlier in this communication, hypercarbia induced noradrenaline release during ether anaesthesia in adrenalectomized dogs (Table VI) and increased the plasma levels of adrenaline and noradrenaline during cyclopropane anaesthesia in intact dogs (Table VII). Furthermore, pronounced increases in plasma adrenaline and noradrenaline occurred in response to asphyxia (hypoxia plus hypercarbia) during cyclopropane anaesthesia in one experiment (Table IX). In this study there was

TABLE IX

Effect of 20 Minutes of "Apnoea in Air" (Preceding the 45' Sample) in a Dog Previously Ventilated with 50 Per Cent Cyclopropane/Oxygen (Group I)

\begin{tabular}{|c|c|c|c|c|c|c|}
\hline & $\mathrm{pH}$ & $\begin{array}{c}\mathrm{pCO}_{2} \\
(\mathrm{~mm} \cdot \mathrm{Hg})\end{array}$ & $\begin{array}{c}\text { Separated } \\
\text { plasma } \\
\text { standard } \\
\mathrm{HCO}_{3}^{-} \\
\left.\text {(mM. } \text { m. }^{-}\right)\end{array}$ & $\begin{array}{r}\text { Adrenaline } \\
(\mu \mathrm{g} . / \mathrm{L} .)\end{array}$ & $\begin{array}{c}\text { Neradrenaline } \\
(\mu \mathrm{g} . / \mathrm{L} .)\end{array}$ & $\begin{array}{c}\text { Oxygen } \\
\text { saturation } \\
\text { (percentage) }\end{array}$ \\
\hline- & 7.41 & 38 & 230 & $\begin{array}{ll}0 & 0\end{array}$ & 0.10 & 99 \\
\hline$+15^{\prime}$ & 741 & 38 & 230 & $\begin{array}{lll}0 & 01\end{array}$ & 003 & 99 \\
\hline$+45^{\prime}$ & 687 & 156 & 228 & 49 & 11 & 42 \\
\hline$+90^{\prime}$ & 721 & 37 & 141 & 36 & 072 & 89 \\
\hline
\end{tabular}

no measurable increase in plasma catecholamine concentration after 15 minutes of uncomplicated cyclopropane anaesthesia (concentrations up to 50 per cent). A period of acute asphyxia then followed, with the respirator disconnected and the animal left in apnoea with the endotracheal tube open to air. During the next 20 minutes arterial $\mathrm{pH}$ fell to $6.87, \mathrm{pCO}_{2}$ rose to $156 \mathrm{~mm}$. $\mathrm{Hg}$, oxygen saturation was reduced to 42 per cent, and plasma adrenaline and noradrenaline increased to 4.9 and $1.1 \mu \mathrm{g} . ; \mathrm{L}$. respectively. Circulating catecholamine levels were still elevated after a subsequent 45 -min. period of ventilation with 100 per cent oxygen $(90-\mathrm{min}$. sample, Table IX), at which time arterial oxygen saturation was still reduced although $\mathrm{pCO}_{2}$ had returned to normal. The low values for arterial $\mathrm{pH}$ and "separated plasma bicarbonate" measured after this period of ventilation reflect the severe metabolic acidosis which resulted from this episode of asphyxia. The findings show that serious physiological insults of this nature during general anaesthesia result in biochemical changes which are not necessarily rapidly reversed.

Ventricular arrhythmias were frequent during ventilation with oxygen and 50 per cent cyclopropane, a concentration which is not uncommonly employed in clinical anaesthesia. Whereas no animals died during anaesthesia with ether, chloroform, halothane, or cyclopropane in concentrations of 30 per cent or below, two animals died as a result of ventricular fibrillation after 45 and 57 minutes of ventilation with 50 per cent cyclopropane/oxygen (data excluded from Table I). In one dog a small rise in plasma adrenaline preceded ventricular fibrillation; the changes measured in the other animal were negligible. While electrocardiography frequently demonstrated supraventricular arrhythmias, persistent ventricular arrhythmias did not occur in any of the six dogs ventilated with 30 per 
cent cyclopropane/oxygen at normal arterial $\mathrm{CO}_{2}$ tensions, nor during the period of cyclopropane anaesthesia with hypercarbia (Table VII), In both cyclopropane groups (Tables I and VII) there was insufficient information to establish any relationship between cardiac arrhy thmias and circulating catecholamines. Cardiac arrhythmias were noted frequently during anaesthesia with 50 per cent cyclopropane/oxygen without detectable increases in plasma adrenaline or noradrenaline, while the state of severe and prolonged asphyxia which occurted in one experiment (Table IX) did not result in ventricular fibrillation in spite of greatly increased levels of plasma adrenaline and noradrenaline.

\section{Clinical Studies}

Cyclopropane anaesthesia. Cyclopropane/oxygen was administered to a total of seventeen patients. The results were divided into those obtained during anaesthesia alone, and those while surgery was proceeding under cyclopropane anaesthesia. Data from six patients were rejected because of moderate respiratory acidosis present on most occasions when blood samples were withdrawn, and from two other patients because no acid-base data were available. The frequency of mild degrees of respiratory acidosis under average clinical conditions is shown by the finding that whereas $\mathrm{pCO}_{2}$ levels were below $55 \mathrm{~mm}$. $\mathrm{Hg}$ at all times in the remaining nine patients, in only five of them were the levels below $49 \mathrm{~mm} . \mathrm{Hg}$ when samples were withdrawn during cyclopropane anaesthesia before surgery. There was no evidence to suggest any difference between plasma catecholamine levels at arterial $\mathrm{pCO}_{2} 49-55 \mathrm{~mm}$. $\mathrm{Hg}$ and those below $49 \mathrm{~mm}$. $\mathrm{Hg}$, nor anydiscrepancy between the values measured during cyclopropane anaesthesia with manually assisted respiration and with mechanical ventilation (positive pressure only). The data from all nine patients are therefore included in the results shown in Table X. In two instances succinylcholine was used (in one case as a single dose prior to intubation and in the other as a continuous infusion).

\section{TABLE $\mathrm{X}$}

Adrenaline (A), Noradrenaline (N), and Total $(A+N)$ Plasma Catecholamine ConCENTRATIONS BEFore aNd DURING ANAESTHEsia (WITH aNd WithoUT SURGERY). CyClopro. Pane, 9 Patients; Diethyl Ether, 16 Patients; Halothane, 11 Patients. T-Test Applied to Paired Samples (Differences from Control Values):

\begin{tabular}{|c|c|c|c|c|c|c|c|c|c|}
\hline & \multicolumn{3}{|c|}{ Control } & \multicolumn{3}{|c|}{ Anaesthesia } & \multicolumn{3}{|c|}{ Anaesthesia + Surgery } \\
\hline & A & $\mathrm{N}$ & Total & A & $\mathrm{N}$ & Total & A & $\mathrm{N}$ & Total \\
\hline $\begin{array}{l}\text { Cyclopropane } \\
\text { Ether } \\
\text { Halothane }\end{array}$ & $\begin{array}{l}0.15 \\
0.13 \\
0.13\end{array}$ & $\begin{array}{l}0.15 \\
0.26 \\
0.34\end{array}$ & $\begin{array}{l}0.30 \\
0.29 \\
0.47\end{array}$ & $\begin{array}{l}0.48 \\
0.26^{*} \\
0.28\end{array}$ & $\begin{array}{l}0.33 \\
0.61 \dagger \\
0.36\end{array}$ & $\begin{array}{l}0.81 \dagger \\
0.87^{*} \\
0.64\end{array}$ & $\begin{array}{l}0.26 \\
0.45 \dagger \\
0.31^{*}\end{array}$ & $\begin{array}{l}0.58^{*} \\
0.68 \dagger \\
0.38\end{array}$ & $\begin{array}{l}0.84 \dagger \\
1.13 \dagger \\
0.70\end{array}$ \\
\hline
\end{tabular}

${ }^{*} p<0.05$

$+p<0.01$

Total plasma catecholamine concentration increased from an average control level of $0.30 \mu \mathrm{g} . / \mathrm{L}$., to $0.81 \mu \mathrm{g}$. $/ \mathrm{L}$. after periods of cyclopropane anaesthesia ranging from 15 to 65 minutes. The increases were highly significant $(p<0.01)$. The average rise in plasma noradrenaline was small and statistically insignificant (Table X). However, convincing increases were measured in occasional patients (Table XI), in the absence of respiratory acidosis. Plasma adrenaline showed 
TABLE XI

Increases in Plasma Noradrenaline in a Patient ANaEsthetized with Cyclopropane; with Further Rises (also Involving Adrenaline) During THE PERIOD OF SURGERY

\begin{tabular}{cccccc}
\hline Time & $\begin{array}{c}\text { Adrenaline } \\
(\mu \mathrm{g} . / \mathrm{L} .)\end{array}$ & $\begin{array}{c}\text { Noradrenaline } \\
(\mu \mathrm{g} . / \mathrm{L} .)\end{array}$ & $\begin{array}{c}\mathrm{pCO} \\
(\mathrm{mm} . \mathrm{Hg})\end{array}$ & $\begin{array}{c}\text { Arterial } \\
\text { pressure } \\
\mathrm{S} / \mathrm{D} \\
(\mathrm{mm} . \mathrm{Hg})\end{array}$ & $\begin{array}{c}\text { Heart } \\
\text { rate }\end{array}$ \\
\hline$-52^{\prime}$ & 0.23 & 0.03 & 41 & $140 / 90$ & 84 \\
+ & 0.43 & 0.86 & 37 & $140 / 100$ & 60 \\
$\begin{array}{c}\text { Surgery } \\
+105^{\prime}\end{array}$ & 0.33 & 1.3 & 39 & $140 / 98$ & 60 \\
$+195^{\prime}$ & 1.2 & 2.0 & 54 & $140 / 86$ & 56 \\
\hline
\end{tabular}

Increase in Plasma Noradrenaline, and Hypertension (Accompanied by Cardiac Arrhythmias) during Respiratory Acidosis in a Patient AnaestheTIZE. WITH CyClOPROPANE

\begin{tabular}{|c|c|c|c|c|c|}
\hline Time & $\begin{array}{l}\text { Adrenaline } \\
(\mu \mathrm{g} . / \mathrm{L} .)\end{array}$ & $\begin{array}{c}\text { Noradrenaline } \\
(\mu \mathrm{g} . / \mathrm{L} .)\end{array}$ & $\begin{array}{c}\mathrm{pCO}_{2} \\
(\mathrm{~mm} \cdot \mathrm{Hg})\end{array}$ & $\begin{array}{c}\text { Arterial } \\
\text { pressure } \\
\mathrm{S} / \mathrm{D} \\
(\mathrm{mm} . \mathrm{Hg})\end{array}$ & $\begin{array}{l}\text { Heart } \\
\text { rate }\end{array}$ \\
\hline $\begin{array}{l}\overline{ }-{ }^{\prime} \\
+25^{\prime}\end{array}$ & $\begin{array}{l}0.0 \\
0.18 \\
0.08\end{array}$ & $\begin{array}{l}0.21 \\
1.1 \\
1.4\end{array}$ & $\begin{array}{l}30 \\
60 \\
69\end{array}$ & $\begin{array}{l}120 / 70 \\
185 / 90 \\
170 / 90\end{array}$ & $\begin{array}{r}72 \\
82 \\
108\end{array}$ \\
\hline
\end{tabular}

small, variable, and statistically insignificant increases during cyclopropane anaesthesia without surgery. The average levels were slightly greater than those of noradrenaline, and also of adrenaline during "cyclopropane anaesthesia with surgery" (Table X). This could be related to a failure to reach a steady staxe of anaesthesia; for example, laryngoscopy and endotracheal intubation were accomplished during the period of cyclopropane anaesthesia alone, and these manœuvres are known to be accompanied by autonomic responses. ${ }^{31}$

During cyclopropane anaesthesia with surgery, total plasma catecholdmine concentration averaged $0.84 \mu \mathrm{g}$. $/ \mathrm{L}$., the increase over control again being highly significant $(p<0.01)$. In this period average plasma noradrenaline $(0.58 \mu \mathrm{g} . \mathrm{E}$. was also significantly $(p<0.05)$ higher than control $(0.15 \mu \mathrm{g}$./L.). It was not possible in this group of patients to show any increase in plasma noradrenaline concentration with time, nor any significant difference between the total plasma catecholamine levels during cyclopropane anaesthesia and those during anaesthesia plus surgery; it is quite possible that the significant rise in plasma noradrenaline during "cyclopropane anaesthesia with surgery" was associated with progressive deepening of anaesthesia (that is, with increasing blood concentrations of cyclopropane), rather than with any effect attendant on operative interference.

Table XI shows the increases in plasma noradrenaline concentration which accompanied progressive respiratory acidosis in a patient anaesthetized with cyclopropane; respiration was assisted but inadequately so to the experienced. observer. Arterial pressure was increased, ventricular arrhythmias were present at variable times throughout the administration, and respiratory depression with laryngeal spasm were troublesome during emergence from anaesthesia. 
Halothane anaesthesia. Fourteen patients were anaesthetized with halothane; because of respiratory acidosis the data from two are excluded. In seven of the remaining twelve patients nitrous oxide/oxygen was used as the vehicle for vaporizing halothane/oxygen, and in the other five cases closed-circuit halothane was used throughout. ${ }^{14}$ During the period of halothane anaesthesia without surgery total plasma catecholamine concentration was increased to an average of $0.64 \mu \mathrm{g} . / \mathrm{L}$. from a control level of $0.47 \mu \mathrm{g}$./L., a change which was insignificant (Table X). Although small increases in plasma adrenaline and noradrenaline were frequently measured, these were too variable for definite trends to be established. The total plasma catecholamine concentration during halothane anaesthesia plus surgery, $0.70 \mu \mathrm{g}$. $/ \mathrm{L}$., was also insignificantly different from control. Average plasma noradrenaline during this period of surgery was not increased over the pre-anaesthetic level of $0.34 \mu \mathrm{g}$. $/ \mathrm{L}$., but adrenaline-showed small but significant increases $(p<0.05)$ to a level of $0.31 \mu \mathrm{g} . / \mathrm{L}$. (control, $0.13 \mu \mathrm{g} . / \mathrm{L}$.$) .$

Ether anaesthesia. Ether anaesthesia was studied in nineteen patients, seventeen of whom were anaesthetized by one of us to ensure a reasonable consistency in technique. A semi-closed method with nitrous oxide/oxygen/ether was used for induction and endotracheal intubation, which was usually accomplished within 10 minutes (and invariably within 20 minutes); thereafter ether/oxygen was administered without rebreathing. A mild degree of oxygen limitation was found to be necessary for two or three minutes at the start of induction, and the data may be affected to a small extent by this and by the short period of nitrous oxide administration. Nevertheless, the technique is a realistic one which is still employed widely. Acid-base data were obtained in all but four cases, which were not excluded from consideration because of the rarity with which respiratory acidosis occurs during ether/oxygen anaesthesia without rebreathing (in our experience).

During ether anaesthesia highly significant increases in plasma noradrenaline were measured $(p<0.01)$, from an average control level of $0.26 \mu \mathrm{g} . / \mathrm{L}$. , to $0.61 \mu \mathrm{g}$. $/ \mathrm{L}$. after periods of anaesthesia ranging from $20-65$ minutes (Table X). Plasma adrenaline showed smaller, but significant $(p<0.05)$, increments to an average of $0.26 \mu \mathrm{g}$. $/ \mathrm{L}$., from a control of $-0.13 \mu \mathrm{g}$. $/ \mathrm{L}$. Ether anaesthesia plus surgery was also associated with an increased plasma noradrenaline level (average $0.68 \mu \mathrm{g} . / \mathrm{L}$.), and with a further rise in adrenaline (to an average of $0.45 \mu \mathrm{g} . / \mathrm{L}$.), the difference from the respective control value with each amine being highly significant $(p<0.001)$.

Table XII presents the data from a group of ten patients anaesthelitutu in an

TABLE XII

Average Results of 10 Patients Anaesthetized with Ether/Oxygen (During a Perion of ONE Hour Prior to SURgery)

\begin{tabular}{lccccccc}
\hline \hline & & $\begin{array}{c}\mathrm{pCO}_{2} \\
(\mathrm{~mm} . \mathrm{Hg})\end{array}$ & $\begin{array}{c}\text { Standard } \\
\mathrm{HCO}^{-} \\
(\mathrm{mM} . / \mathrm{L} .)\end{array}$ & $\begin{array}{c}\text { Adrenaline } \\
(\mu \mathrm{g} . / \mathrm{L} .)\end{array}$ & $\begin{array}{c}\text { Noradrenaline } \\
(\mu g . / \mathrm{L} .)\end{array}$ & $\begin{array}{c}\text { Mean } \\
\text { arterial } \\
\text { pressure }\end{array}$ & $\begin{array}{c}\text { Heart } \\
\text { rate }\end{array}$ \\
\hline Control & 7.411 & 35.4 & 2305 & 0.11 & 0.28 & 105 & 76 \\
$15-30^{\prime}$ & 7.378 & 363 & 21.30 & 0.33 & 0.62 & 105 & 92 \\
$40-60^{\prime}$ & 7.403 & 34.8 & 21.98 & 0.22 & 0.62 & 99 & 91 \\
\hline
\end{tabular}


identical fashion with semi-closed nitrous oxide oxygen ether (for a period of 10-20 minutes), followed by ether/oxygen for periods up to 65 minutes, without surgical intervention. An accurate assessment of non-respiratory acid-base changes was attempted by using the measurement of whole blood "standard

TABLE XIII

Correlatton Coefficient $(r)$ Values for Variables MEasured during Ether Anaesthesia (see. Tables IV and VI, and Text)

\begin{tabular}{|c|c|c|c|c|}
\hline & Total amines & Adrenaline & Noradrenaline & $\begin{array}{l}\text { Percentage } \\
\text { change in } \\
\text { mean arterial } \\
\text { pressure }\end{array}$ \\
\hline $\begin{array}{l}\text { Ether Concentration } \\
\text { Intact dogs } \\
\text { Adrenalectomized dogs } \\
\text { Humans }\end{array}$ & $\begin{array}{ll}0.582 \dagger \\
0 & 132 \\
0 & 652 \dagger\end{array}$ & $\begin{array}{c}0467^{*} \\
0 \overline{090}\end{array}$ & $\begin{array}{l}0.164 \\
0 . \overline{760 \dagger}\end{array}$ & $\begin{array}{l}-0.565 \dagger \\
-0.701 \dagger\end{array}$ \\
\hline $\begin{array}{l}\text { Change in } \mathrm{HCO}_{3}^{-} \\
\text {Intact dogs } \\
\text { Adrenalectomized dogs } \\
\text { Humans }\end{array}$ & $\begin{array}{rl}-0 & 760 \dagger \\
-0 & 119 \\
0 & 021\end{array}$ & $\begin{array}{c}-0.847 \dagger \\
0 \overline{097}\end{array}$ & & \\
\hline
\end{tabular}

${ }^{*} p<0.05$

$\dagger p<0.01$

bicarbonate."18.30 Table XII shows that a small but definite (and significant, $p<0.01)$ reduction in "standard bicarbonate" occurred during ether anaesthesia. The greater fall $(1.8 \mathrm{mM} . / \mathrm{L}$.) was measured after the induction period, and could therefore be associated with the use of nitrous oxide. The level later showed some return toward the pre-anaesthetic value. Comparison of plasma adrenaline and "whole blood standard bicarbonate" levels, at both periods (Table XII), failed to show significant correlation. During ether anaesthesia arterial pressure showed little change, but there were incerases in heart rate and highly significant rises in plasma noradrenaline $(p<0.01)$, with smaller increases in the level of adrenaline (which were also significant, $p<0.05$ ). From Figure 7 (data from four patients of Table XII) a direct correlation of increases in plasma noradrenaline with ether concentration is evident. The coefficient of correlation $(r=0.760)$ is significant $(p<0.05)$; but the number of observations is too small to allow a definite conclusion.

\section{Discussion}

While the output of transmitter substance (noradrenaline) at adrenergic nerve

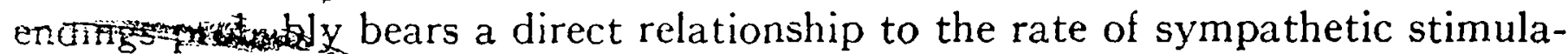
tion, certain pharkacological agents have been shown to affect the amounts of transmitter released at gixen rate of stimulation..$^{32}$ The interpretation of this is that release and destruction intimately related at sympathetic receptor sites. When the adrenergic receptors are ascupied" by adrenergic blocking drugs such as dibenzyline, metabolic transformation of tansmitter substance is interfered with and the plasma concentration rises. In a previoustudy, for example, it was shown that plasma noradrenaline levels in adrenalectomized dogs subjected to haemorrhage were much higher if the animals were pre-treated with dibenzyline ${ }^{4}$. in this instance the increased noradrenaline "release" could not be accounted 


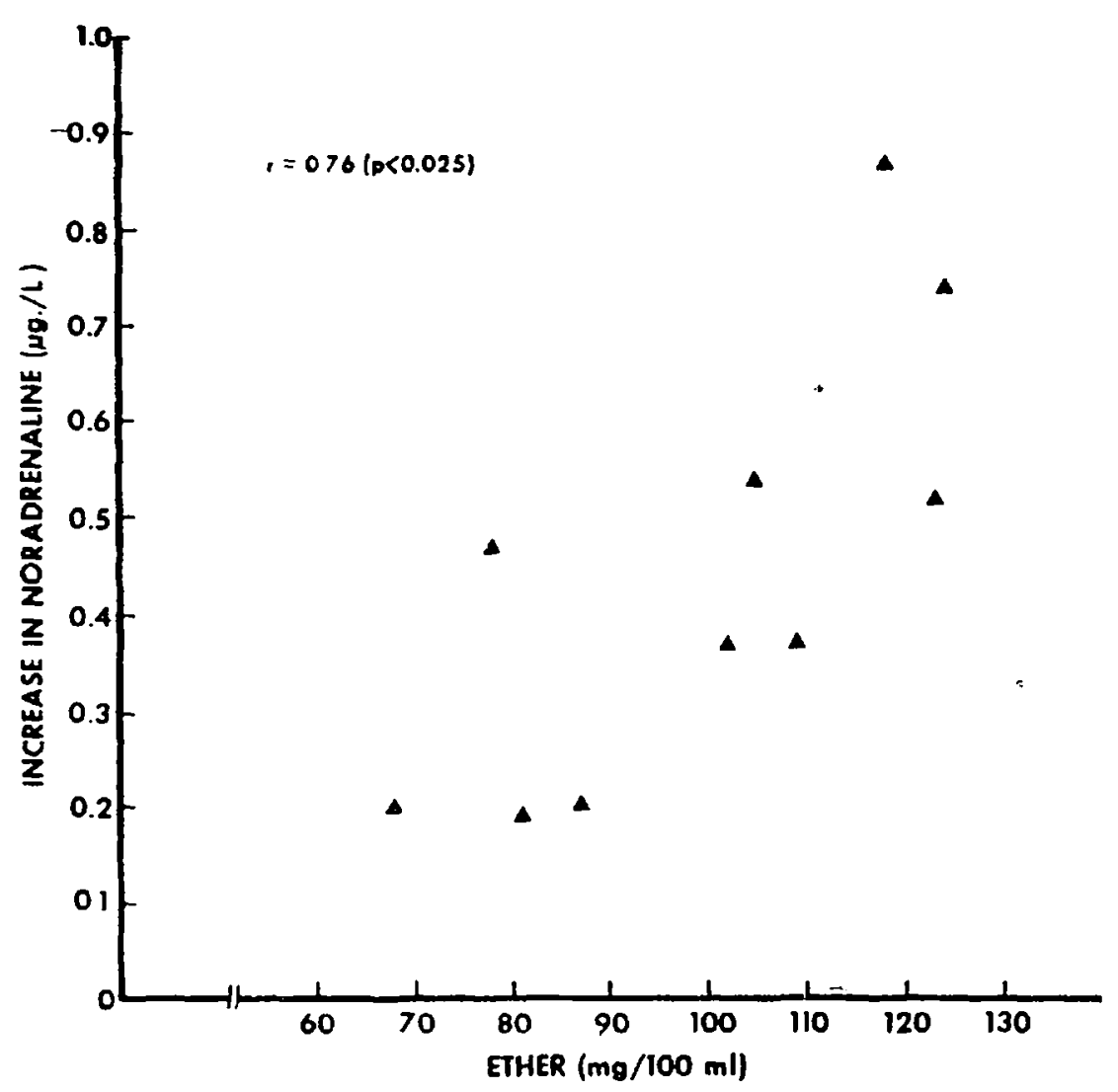

FIGURE 7. Relation between increases in plasma noradrenaline and blood ether concentrations in four patients during ether/oxygen anaesthesia (average duration one hour), prior to surgery.

for solely on the basis of a higher rate of sympathetic nervous discharge than was occurring in the untreated animals. A similar effect may occur with other adrenergic blocking drugs. These experimental observations are emphasized because they show that blockade of the effects of endogenously released catecholamines can be accompanied by increases in the levels circulating in the blood stream. On the basis of infusion experiments it has been deduced that general anaesthetic agents are unlikely to have any such effect; ${ }^{33}$ however, metabolic breakdown of catecholamines administered by exogenous infusion or liberated from the adrenal medulla appears to be carried out in the liver by catechol O-methyltransferase, ${ }^{34}$ whereas local transformation of catecholamines released in the tissues may involve mono-amine oxidase, ${ }^{35}$ so that the effect of anaesthetics on the disposal of locally released transmitter is not necessarily the same as that on material infused exogenously" or from the adrenal medulla.

In attempting some interpretation of the present studies, it has been necessary to assume that measurement of increased plasma catecholamine concentrations implies an increased rate of sympathetic discharge. In the absence of convincing evidence to the contrary this assumption is probably valid, but might require modification at a later date.

It is not known whether increased plasma catecholamine levels during ether anaesthesia result from direct sympathetic excitation, or whether they can be regarded as a compensatory phenomenon related to the direct myocardial and vasomotor depressant properties of diethyl ether. It has been suggested that activation of the ascending reticular formation occurs during light ether anaesthesia ${ }^{36}$ but more complete;confirmation is required. ${ }^{37}$ Hy persynchronous, seizure- 
like activity in rhinencephalic structures (including the posterior hypothalamus) has been reported during certain phases of ether anaesthesia, ${ }^{38}$ while depletion of noradrenaline from the hypothalamus also occurs. ${ }^{39}$ These and other experimental observations point to an increase in subcortical neuronal activity during various stages of ether anaesthesia, but it clearly is not yet possible to describe the neurophysiological actions of diethyl ether in simple terms of "stimulation" or "depression."

The view of catecholamine responses as a vital reflex mechanism in the maintenance of homeostasis during ether anaesthesia is supported by the experiments of Brewster and associates, ${ }^{40}$ who considered that direct depression of cardiac and vascular muscle was antagonized quantitatively by release of adrenaline and noradrenaline at rates of liberation approximating $1 \mu \mathrm{g} . / \mathrm{kg} . / \mathrm{min}$. In the present studies the highest total plasma catecholamine level measured during ethet a aesthesia was $11 \mu \mathrm{g}$./L. in a dog breathing ether/air, so that the circulating concentrations were much lower than would result from this rate of liberation. It is probably not possible to draw comparisons on a quantitative basis, between the actions of infused catecholamines and those of adrenergic nerve stimulation (as a result of which only small quantities of transmitter will reach the circulation).

Although in the present study arterial pressure tended to fall progressively during ventilation with ether/oxygen in adrenalectomized dogs (from control levels which were lower than in intact animals), there was no convincing evidence of impending circulatory collapse at blood levels as high as $130 \mathrm{mg} . / 100 \mathrm{ml}$. Several studies have demonstrated that the function of the sympathetic nervous system is essential for maintenance of normal circulation during ether anaesthesia $^{40.41}$ but it is difficult to consider adrenal medullary liberation of catecholamines as a vital component of the reflex response to ether anaesthesia. It appears very probable, also, that "peripheral" sympathetic stimulation during ether ariaesthesia in dogs is less than maximal, because superimposed hypercarbia resulted in considerably higher plasma noradrenaline levels in the adrenalectomized animals. The possibility must be considered, in this connection, that an increased $\mathrm{pCO}_{2}$ or reduced tissue $\mathrm{pH}$ could affect the rate of diffusion from, and breakdown at, the site of release. Also pertinent to the peripheral sympathomimetic effects of ether is the rise in blood sugar during hypercarbia in the adrenalectomized dogs, which could be due to an increase in sympathetic activity above that produced by ether alone, although carbon dioxide can probably liberate glucose by a direct action on hepatic cells.42

Burn and Rand ${ }^{43}$ have suggested that the "role" of adrenal medullary noradrenaline may be the replenishment of noradrenaline in depleted peripheral "stores." The fact that acutely adrenalectomized dogs can withstand at least two hours of moderately deep ether anaesthesia, and other stresses such as severe carbon dioxide accumulation, ${ }^{6}$ is in keeping with a concept such as this, which relegates adrenal medullary noradrenaline to a secondary position.

The functions of the "neural" (extra-adrenal) and "humoral" (adrenal medullary) elements of the sympathetic nervous system should probably be clearly differentiated. At the same rates of electrical stimulation it was shown that the neural component produced effects many times greater than those elicited 
by adrenal medullary secretion. ${ }^{44}$ It seems more than probable that the "significance" of an increased circulating level of adrenaline and noradrenaline lies less with the effects induced indirectly via the blood stream on organs such as the heart, than with the fact that it is a manifestation of generalized sympathetic excitation, the more important component of which is an intimate liberation of noradrenaline at adrenergic nerve endings. At these sites the effect of released transmitter substance on local vasomotor tone or on cardiac rate and rhythm is much more intense than that of equivalent amounts carried by the blood stream. ${ }^{44}$ The measurement of increased plasma levels of noradrenaline during ether anaesthesia in adrenalectomized dogs presumably implies widespread release from sympathetic nerve endings. Information is required concerning the liberation of noradrenaline from the hear $t^{45}$ and brain ${ }^{39}$ during general anaesthesia.

Many effects of ether anaesthesia in the dog are similar to those of adrenaline. ${ }^{25}$ The significant inverse correlation between plasma catecholamine concentration and "separated plasma standard bicarbonate" established in intact dogs in the present study confirms the close interdependence of sympatho-adrenal excitation and metabolic acidosis during ether anaesthesia ${ }^{26}{ }^{26}$ this being further demonstrated by a lesser degree of acidosis in the adrenalectomized animals. It is apparent from our findings and those of Brewster ${ }^{26}$ that minimal acid-base (and plasma catecholamine) changes occur even in intact dogs at blood ether levels below about $100 \mathrm{mg}$. $/ 100 \mathrm{ml}$. At higher levels of blood ether acid-base changes still occur to some effect after total sympathetic blockade. ${ }^{26}$ It has been suggested that a direct action of ether is involved, this being enhanced by adrenalectomized animals by peripheral sympathetic stimulation and extra-adrenal noradrenaline release. This appears more probable than an effect of diminished tissue perfusion or anoxia which although certain to be followed by a metabolic acidosis ${ }^{46}$ could hardly account for the changes measured in the adrenalectomized dogs in the present study - there was no serious circulatory impairment at blood ether levels of about $130 \mathrm{mg} . / 100 \mathrm{ml}$., and oxygenation was fully maintained. It is possible that noradrenaline may to some extent stimulate anaerobic carbohydrate metabolism, although there is evidence against this. ${ }^{47}$ The severe metabolic acidosis in the dogs breathing ether/air (average blood levels $130 \mathrm{mg} . / 100 \mathrm{ml}$.), which also showed a reduced arterial oxygen saturation, suggests the enhancement of acid-base changes by mild anoxia; this may be of some concern in view of recent attempts to revive the use of air rather than oxygen in anaesthetic mixtures..$^{48.49}$

Clinical observations reveal the marked respiratory stimulation evoked by adrenaline injected subcutaneously during ether anaesthesia in man. It is conceivable to consider a relationship between the fact that pulmonary ventilation is well maintained during ether anaesthesia and the following experimental findings: impulse conduction through the lateral reticular formation is still maintained after ether anaesthesia is established ${ }^{50}$ discharges from respiratory nerve cells are maximal in the lateral reticular region; $;^{51}$ and activation of the reticular system is readily induced by adrenaline and noradrenaline. ${ }^{52}$ Respiratory activity, and that of nerve cells in the brain stem closely concerned with cardiovascular control, may well be affected by, and maintained at a high level under the influence of, endogenously released catecholamines. Thus a self perpetuating 
cycle of reciprocal activation could occur, involving catecholamine release and central excitation.

It is of interest to note that in our studies the circulating noradrenaline concentration measured during ether anaesthesia in man was of the same order as that in adrenalectomized dogs, at roughly similar blood ether concentrations. It appears, moreover, that noradrenaline release in man during ether anaesthesia could occur largely from areas outside the adrenal gland, ${ }^{33,53}$ although we have no studies to demonstrate this. Since the findings from the present study were that small increases in plasma adrenaline occurred in man, together with a mild metabolic acidosis, our data would be quite compatible with the assumption that the responses to ether anaesthesia in the dog and man are similar qualitatively if not quantitatively. The outstanding difference is apparently an exaggerated response of the adrenal medulla in dogs. Other evidence suggests that adrenal medullary discharge during ether anaesthesia is minimal or absent in $\operatorname{man}^{33,53}$ but it is difficult to believe that an agent which induces an increased discharge rate in sympathetic nerves would not sometimes release adrenal medullary hormones.

The fact that the adrenal medulla is more responsive, or is stimulated to a greater extent, in the dog, suggests that in this species the "humoral" component of the sympathetic nervous system is of more physiological "importance" than in man, whose peripheral autonomic control has probably developed to a greater extent because of the need to maintain circulation in the upright position.

In general the impression is left that the sympatho-adrenal excitation induced b) diethyl ether occurs because of a direct or "irritant" action of ether itself, probably in the central nervous system. This may involve any nerve cells in the brain stem, or spinal cord ${ }^{25}$ which can influence the rate of efferent sympathetic discharge. An effect on chemoreceptors ${ }^{54}$ might be a factor of importance, while "chemical" excitation of the adrenal medulla ${ }^{55}$ cannot be entirely rejected. This does not in any way refute the part played by the sympathetic nervous system in maintaining circulatory homeostasis in the face of direct myocardial depression, but the fundamental compensatory mechanisms operating under the influence of ether probably closely resemble those occurring during the administration of other non-hypotensive anaesthetic agents. From the significant direct correlation demonstrable between blood ether and total catecholamine concentrations in dogs (and from suggestive findings in relation to plasma noradrenaline in man), it could be implied that the response of the sympathetic nervous system during ether anaesthesia bears a quantitative relationship not necessarily to the degree of myocardial or vascular depression, but to the blood ether concentration. The pronounced increases in plasma catecholamine levels measured in dogs at blood ether concentrations above $180 \mathrm{mg} . / 100 \mathrm{ml}$. are clearly unable to antagonize the severe hypotension encountered at such excessively deep levels of anaesthesia.

Since plasma noradrenaline did not show significant increases during cyclopropane anaesthesia in the $d o g$, it appears that widespread sympatho-adrenal excitation is not induced by cyclopropane in this species. It is considered that while the rather small increases in plasma adrenaline could be an effect of cyclo- 
propane it is more likely that they represent adrenal medullary stimulation from blood sampling or "experimental stress." Blood pressure was reduced by concentrations of 50 per cent cyclopropane when given continuously, but in spite of experimental evidence in animals and man to show that many circulatory reflexes are not greatly modified during cyclopropane anaesthesia, ${ }^{1}$ it appears that sympatho-adrenal activation is not a "physiologically essential" component of the homeostatic mechanisms operating during anaesthesia with this agent. This seems to cast further doubt on the likelihood of sympatho-adrenal stimulation being "compensatory" during ether anaesthesia.

The results of several clinical studies suggest a heightened degree of sympathetic ${ }^{28}$ and parasympathetic ${ }^{56}$ tonus during cyclopropane anaesthesia in man. The data from the present study also indicate that cyclopropane anaesthesia can be accompanied by noradrenaline release in man, but the response appears to be variable. In our studies diethyl ether produced more consistent and definite changes. Differences in the data obtained with these two agents, and between different laboratories, could be at least partly associated with variations in pulmonary ventilation, which in the present study was assisted or controlled in every patient anaesthetized with cyclopropane, whereas this was found to be unnecessary during ether anaesthesia.

Splanchnic and renal vasoconstriction occur during cyclopropane anaesthesia, ${ }^{57}$ and there is an increase in central venous pressure ${ }^{58}$ In a recent study ${ }^{56}$ cardiac output was increased, together with total peripheral resistance (calculated from the data). These could be relatively independent manifestations of central sympathetic excitation, but it could also be suggested that a primary effect of cyclopropane might be an increase in vascular tone-it has been stated that vascular sensitivity to catecholamines is enhanced by anaesthetic concentrations of cyclopropane. ${ }^{1}$ As a result of increased vascular resistance, and because of well-maintained reflex mechanisms, there could be a "compensatory" increase in cardiac force of contraction. Arrhythmias would be liable to occur because of increased noradrenaline release and cardiac work, particularly if cyclopropane sensitized cardiac muscle. As the blood concentration of cyclopropane fell at the end of administration, cardiac force would be lessened, the increased vascular tone reduced, and a ready explanation for cyclopropane "shock" would be available; the whole picture would be intensified by respiratory acidosis, a reduced circulating blood volume, effects of movement, reduction in arterial oxygen saturation, and so on. ${ }^{59}$

Plasma concentrations of noradrenaline might be increased during cyclopropane anaesthesia as a result of liberation of transmitter substance at adrenergic nerve endings concerned with regulation of vascular tone, with a small contribution from cardiac sympathetic nerves. It would be interesting to know whether an increased plasma noradrenaline concentration occurs predominantly in those patients who show a high peripheral resistance and an increased cardiac stroke volume. Also, more information is needed about the possibility of a primary sensitizing effect of cyclopropane to normal amounts of sympathetic transmitter substance liberated at nerve terminals within the heart. Cardiac arrhythmias during cyclopropane anaesthesia are not readily explicable only on a basis of 
increased noradrenaline release from nerve-endings within the heart, since this almost certainly also occurs during ether anaesthesia, which is rarely accompanied by ventricular arrhythmias.

The fact that plasma catecholamine levels are not significantly increased during uncomplicated halothane anaesthesia in man or dogs suggests that sympathetic responses are not directly excited by this agent. Studies reported previously showed that halothane does not effectively block the catecholamine responses to haemorrhage and hypercarbia in $\operatorname{dogs},{ }^{9}$ although without more extensive comparative studies with other agents it can not be affirmed that some reduction does not occur. There is some evidence to suggest that the catecholamine responses to hypercarbia during halothane anaesthesia in man are less marked than during anaesthesia with cyclopropane. ${ }^{60}$ Such comparisons are difficult to interpret without more detailed knowledge of "levels" of anaesthesia, in neurophysiological terms. The studies reported here seem to indicate that reflex or direct sympatho-adrenal responses to haemorrhage, asphyxia, and hypercarbia are well maintained during anaesthesia with diethyl ether and cyclopropane.

Because of losses in recovery of catecholamines from plasma, and other problems in methodology, it is considered that increases in plasma catecholamine levels during general anaesthesia are in reality greater than indicated, while it is probable that minimal changes have frequently gone undetected.

Finally, it is necessary to emphasize the wide variations encountered in both dogs and patients, and it should be noted that statistical inferences indicate probabilities; thus, while changes in plasma catecholamine concentrations are less likely to occur during anaesthesia with halothane than with ether or cyclopropane, their occurrence at any time in any individual patient is not precluded.

\section{SUMmary}

Plasma catecholamine levels were studied during general anaesthesia with diethyl ether, cyclopropane, and halothane in dogs and human subjects. Anaesthesia with ether/oxygen caused highly significant increases in plasma noradrenaline in dogs and man. The response was less marked in man, but a significant direct correlation could be established (in a small number of patients) between the rise in plasma noradrenaline and blood ether concentrations during ether ànesthesia without surgical interference. Plasma adrenaline was also significantly increased in dogs during ether anaesthesia, and in man to a lesser extent; highly significant rises were measured during surgery in man. The severe metabolic acidosis induced by diethyl ether in the dog bore a direct relationship to circulating catecholamine concentration and was greatly reduced by bilateral adrenalectomy. A mild but definite metabolic acidosis was measured during nitrous oxide/ oxygen/ether and ether/oxygen anaesthesia in man. In adrenalectomized dogs, variable moderate rises in plasma noradrenaline were measured during ether anaesthesia, from which it is inferred that in this species the rise in plasma noradrenaline stems partly from extra-adrenal areas. Since hypercarbia superimposed on ether anaesthesia in adrenalectomized dogs caused further increases in plasma noradrenaline, it is considered that the extra-adrenal sympathetic excitation induced by ether is submaximal. 
Cyclopropane anaesthesia in dogs with normal $\mathrm{pCO}_{2}$ was accompanied by very small increases in plasma adrenaline, probably accounted for by blood sampling. In man, cyclopropane anaesthesia was associated with a significant increase in total plasma catecholamine concentration, with definite rises in plasma noradrenaline in certain patients at both normal and raised levels of arterial $\mathrm{pCO}_{2}$, the increases at normal $\mathrm{pCO}_{2}$ becoming significant statistically only as a result of deeper anaesthesia, because of an effect of surgery, or both.

Halothane did not produce significant increases in plasma catecholamine concentration in dogs or man, although plasma adrenaline was significantly increased during surface surgery under halothane anaesthesia in man.

Elevated plasma catecholamine levels as a result of haemorrhage during ether anaesthesia, hypercarbia and asphyxia during cyclopropane anaesthesia. and hypercarbia during ether anaesthesia in adrenalectomized dogs, togethe with studies previously reported, indicated that the currently used general anaesthetic agents do not have any major "dampening" effect on the sympathoadrenal responses to the compron forms of stimulation encountered in the operating room.

\section{ACKNOWLEDGMENTS}

This study was supported by grants from the Cooper Fund, McGill University, from Montreal Neurological Institute, and from Parke-Davis and Company. The clinical studies, carried out at Queen Mary Veterans' Hospital, formed Veterans' Administration Research Project No. 30-55. The co-operation of many members of the anaesthetic, surgical, and nursing staff is acknowledged. Technical assistance was provided by Mrs. J. Joba, Anaesthesia Laboratory, Montreal Neurological Institute.

\section{RÉSLMÉ}

Nous avons étudié chez des chiens et chez des humains, au cours de l'anesthésie générale à l'éther, au cyclopropane et à l'hạlothane, les variations du taux de catécholamine dans le plasma. L'anesthésie à l'éther et oxygène a entraîné une augmentation importante du taux de noradrénaline dans le plasma aussi bien chez les chiens que chez l'homme. Chez l'homme, la réponse était moins marquée, mais on a pu établir une corrélation directe (chez un petit nombre de malades) entre l'augmentation du taux de noradrénaline dans le plasma et la concentration du sang en éther au cours de l'anesthésie à l'éther sans chirurgie. Le taux d'adrénaline dans le plasma était également augmenté de façon importante chez les chiens au cours de l'anesthésie à l'éther, mais chez l'homme, à un degré moindre; au cours de la chirurgie on a également observé des augmentations considérables. L'acidose métabolique marquée produite par l'éther chez le chien est directement proportionnelle au taux de catécholamine circulant, et elle a été considérablement réduite par la surrénalectomie bilatérale. Nous avons également dépisté, chez l'homme, au cours de l'anesthésie au protoxide/oxygène/éther, et au cours de l'anesthésie à l'éther/oxygène, une acidose légère mais positive.

Chez les chiens surrénalectomisés, nous avons observé une augmentation légère et variable du taux d'adrénaline dans le plasma, au cours de l'anesthésie 
à l'éther, ce qui nous incite à croire que, chez cet animal du moins, l'augmentation du taux d'adrénaline dans le plasma provient, en partie, d'endroits autres que la surrénale. Etant donné que si l'on ajoute l'hypercarbie à l'anesthésie à l'éther, chez des chiens surrénalectomisés, l'on observe une augmentation additionnelle du taux de noradrénaline dans le plasma, l'on est porté à croire que l'excitation sympathique extrasurrénalienne produite par l'éther est une excitation probablement submaximale.

Au cours de l'anesthésie au cyclopropane, chez des chiens conservant un $\mathrm{P} \mathrm{CO}_{2}$ normal, l'on a constaté de légères augmentations du țaux d'adrénaline dans le plasma, occasionnées probablement par l'échantillonnage du sang. Chez l'homme, l'anesthésie au cyclopropane s'est accompagnée d'une augmentation importante du taux de catécholamine dans le plasma et, chez certains malades dont le $\mathrm{P} \mathrm{CO}_{2}$ était normal et chez d'autres dont le $\mathrm{P} \mathrm{CO}_{2}$ était élevé, d'une augmentation nette du taux de noradrénaline dans le plasma. Ces augmentations, lorsque le $\mathrm{P} \mathrm{CO}_{2}$ était normal, prenaient une valeur statistique appréciable, si on leur attribue comme cause, soit une anesthésie plus profonde, soit un effet de la chirurgie, soit les deux effets ensemble.

En ce qui concerne l'halothane, aussi bien chez les chiens que chez, l'homme nous n'avons pas observé, au cours de l'anesthésie, d'augmentation importante du taux de catécholamine dans le plasma, bien que au cours de la chirurgie de surface chez l'homme anesthésié à l'halothane, nous avons trouvé une augmentation importante du taux d'adrénaline dans le plasma.

Les taux élevés de catécholamine dans le plasma, résultant de l'hémorragie durant l'anesthésie à l'éther, l'hypercarbie et l'asphyxie durant l'anesthésie au cyclopropane, l'hypercarbie durant l'anesthésie à l'éther chez des chiens surrénalectomisés, les études citées antérieurement, tout indique que les agents anesthésiques généraux n'exercent pas d'effets inhibiteurs marqués sur les réponses sympathicosurrénaliennes aux diverses formes de stimulation subies dans les salles d'opération.

\section{REFERENCES}

1. Price, H. L. General Anesthesia and Circulatory Homeostasis. Physiol. Rev. 40: 187 (1960).

ฉ. Millar, R. A., \& Benfey, B. G. The Fluorimetric Estimation of Adrenaline and Noradrenaline during Haemorrhagic Hypotension. Brit. J. Anaesth. 30: 159 (1958).

3. Millar, R. A., \& Benfey, B. G. Plasma Adrenaline and Noradrenaline Levels during Haemorrhage Induced after Chlorpromazine Injection. Brit. J. Anaesth. 31 : 258 (1959).

4. Millar, R. A., Keener, E. B., \& Benfey, B. G. Plasma Adrenaline and Noradrenaline after Phenoxybenzamine, and during Haemorrhagic Hypotension in Normal and Adrenalectomized Dogs. Brit. J. Pharmacol. 14: 9 (1959).

5. Millar, R. A. Plasma Adrenaline and Noradrenaline during Diffusion Respiration. J. Physiol. 150: 79 (1960).

6. Millar, R. A., \& Morris, M. E. Apneic Oxygenation in Adrenalectomized Dogs. Anesthesiology 22: 433 (1961).

7. Millar, R. A., \& Morris, M. E. Norepinephrine Release during Respiratory Acidosis in Adrenalectomized Dogs. Anesthesiology 22: 62 (1961).

8. Millar, R. A., Brindle, G. F., \& Gmbert, R. G. B. Studies with an Organic Buffer (T.H.A.M.) during Apnoeic Oxygenation in. Dogs. Brit, J. Anaesth. 32: 248 (1960). 
9. Millar, R. A., \& Morris, M. E. Induced Sympathetic Stimulation during Halothane Anaesthesia. Canad. Anaesth. Soc. J. 7: 423 (1960).

10. Millar, R. A., \& Morris, M. E. A Study of Methoxyflurane Anaesthesia. Canad. Anaesth. Soc. J. 8: $210(1961)$.

11. Benfex, B. G., \& Millar, R. A. Catechol Amines in Blood, Urine, and Tumour in a Patient with Phaeochromocytoma. Canad. Med. Asssoc. J. 77: 701 (1957).

12. Bromage, P. R., \& Millar, R. A. Epidural Blockade and Circulating Catechol Amine Levels in a Child with Phaeochromocytoma. Canad. Anaesth. Soc. J. 5: 282 (1958).

13. Conn, A. W., \& Millar, R. A. Post Occlusion Hypertension and Plasma Catecholamine Levels. Canad. Anaesth. Soc. J. 7: 443 (1960).

14. Marretr, H. R. Halothane: Its Use in Closed Circuit. Brit. Med. J. ii: 331 (1957).

15. Euler, U. S. v., \& Floding, I. Fluorimetric Micromethod for Differential Estimation of Adrenaline and Noradrenaline. Acta Physiol. Scand. (suppl. 118) 39: 46 (1955).

16. Astrup, P., \& Schrøder, S. Apparatus for Anaerobic Determination of the pH of Blood at 38 Degrees Centigrade. Scand. J. Clin. Lab. Invest. 8: 30 (1956).

17. Astrup, P. Simple Electrometric Technique for Determination of Carbon Dioxide Tension in Blood and Plasma, Total Content of Carbon Dioxide in Plasma, and Bicarbonate Content in "Separated" Plasma at a Fixed Carbon Dioxide Tension (40 mm. Hg). Scand. J. Clin. Lab. Invest. 8: 33 (1956).

18. Siggaard Andersen, O.; Engel, K.; Jørgensen, K.; \& Astrup, P. A Micto Method for Determination of $\mathrm{pH}$, Carbon Dioxide Tension, Base Excess and Standard Bicarbonate in Capillary Blood. Scand. J. Clin. \& Lab. Invest. 12: 172 (1960).

19. Nahas, G. G. Spectrophotometric Determination of Hemoglobin and Oxyhemoglobin in Whole Hemolyzed Blood. Science 113: 723 (1951).

20. Price, H. L., \& Price, M. L. Determination of Diethyl Ether in Blood. Anesthesiology 17: 293 (1956).

21. Shaffer, P. A., \& Ronzoni, E. Ether Anesthesia: Determination of Ethyl Ether in Air and Blood, and its Distribution Ratio between Blood and Air. J. Biol. Chem. 57: 741 (1923).

22. Varley, H. Practical Clinical Biochemistry. 2nd. ed. London: William Heinemann (1960).

23. Snedecor, G. W. Statistical Methods. 5th ed. Iowa: Iowa State College Press (1959).

24. Bunker, J. P.; Beecher, H. K.; Briggs, B. D.; Brewster, W. R.; \& Barnes, B. A. Metabolic Effects of Anesthesia. II. A Comparison of Acid-Base Equilibrium in Man and in Dogs During Ether and During Cyclopropane Anesthesia. J. Pharmacol. \& Exp. Ther. 102: $62(1951)$.

25. Beatia, B. B., \& Burn, J. H. Action of Ether on the Sympathetic System. J. Physiol. 78: 257 (1933).

26. Brewster, W. R., Bunker, J. P., \& Beecher, H. K. Metabolic Effects of Anaesthesia. VI. Mechanisms of Metabolic Acidosis and Hyperglycemia during Ether Anesthesia in Dogs. Am. J. Physiol. 171: 37 (1952).

27. Keeton, R. W., \& Ross, E. L. Mechanism of Ether Hyperglycemia. Am. J. Physiol. 48: 146 (1919).

28. Price, H. L.; Lurie, A. A.; Jones, R. E.; Price, M. L.; \& Linde, H. W. Cyclopropane Anesthesia. II. Epinephrine and Norepinephrine in Initiation of Ventricular Arrhythmias by Carbon Dioxide Inhalation. Anesthesiology 19:619 (1958).

29. Hamelberg, W.; Sprouse, J. H.; Mahaffey, J. E.; \& Richardson, J. A. Catechol Amine Levels during Light and Deep Anesthesia.-Anesthesiology 21: 297 (1960).

30. Jørgensen, K., \& Astrup, P. Standard Bicarbonate, Its Clinical Significance, and a New Method for its Determination. Scand. J. Clin. \& Lab. Invest. 9: 122 (1957).

31. King, B. D.; Harris, L. C.; Greifenstein, F. E.; Elder, J. D., Jr.; \& Dripps, R. D. Reflex Circulatory Responses to Direct Laryngoscopy and Tracheal Intubation Performed during General Anesthesia. Anesthesiology 12: 556 (1951).

32. Brown, G. L., \& GillespiE, J. S. The Output of Sympathetic Transmitter from the Spleen of the Cat. J. Physiol. 138: 81 (1957). 
33. Price, H. L.; Linde, H. W.; Jones, R. E.; Black, G. W.; \& Price, M. L. SympathoAdrenal Responses to General Anesthesia in Man and Their Relation to Hemodynamics. Anesthesiology 20: 563 (1959).

34. Axelrod, J. Metabolism of Epinephrine and Other Sympathomimetic Amines. Physiol. Rev. 89: 751 (1959).

35. Spector, S.; Kuntzman, R.; Shore, P. A.; \& Brodie, B. B. Evidence for Release of Brain Amines by Reserpine in Presence of Monoamine oxidase Inhibitors: Implication of Monoamine oxidase in Norepinephrine Metabolism in Brain. J. Pharmacol. 190: 256 (1960).

36. Rossi, G.F., \& Zirondoli, A. On the Mechanism of the Cortical Desynchronization Elicited by Volatile Anesthetics. EEG Clin. Neurophysiol. 7: 383 (1955).

37. Schlag, J., \& Brand, H. An Analysis of Electrophysiological Events in Cerebral Structures during Ether Anesthesia. EEG Clin. Neurophysiol. 10: 305. (1958).

38. Domino, E. F., \& UEki, S. Differential Effects of General Anesthetics on Spontaneous Electrical Activity of Neocortical and Rhinencephalic Brain Systems of the Dog. J. Pharmacol. \& Exp. Ther. 12r: 288 (1959).

39. VogT, M. Concentration of Sympathin in Different Parts of the Central Nervous System under Normal Conditions and after Administration of Drugs. J. Physiol. 123: 451 (1954).

40. BREwSter, W, R.; ISAaCs, J. P., \& Wain $\varnothing$-Anderson, T: Depressant Effect of Ether on the Myocardium of the Dog and its Modification by Reflex Release of Epinephrine and Norepinephrine. Am. J. Physiol. 1\%5: 399 (1953).

41. MCAllister, F.F., \& Root, W.S. Circulatory Responses of Normal and Sympathectomized Dogs to Ether Anesthesia. Am. J. Phy'siol. 133: 70 (1941).

42. Fexir, W. O., \& Asano, T. Effects of Carbon Dioxide Inhalation on Potassium Liberation from the Liver. Amer. J. Physiol. 185: 567 (1956).

43. BLRn, J. H., \& Rand, M. J. New Observations on the Sympathetic Postganglionic Mechanism. Amer. J. Med. 29: 1002 (1960).

44. Celander, O. The Range of Control Exercised by the Sympathico-adrenal System. Acta Physiol. Scand. (suppl. 116) 32: (1954).

45. Outschoorn, A. S., \& Vogt, M. The Nature of Cardiac Sympathin in the Dog. Brit. J. Pharmacol. 7: 319 (1952).

46. Seligman, A. M.; Frank, F. A.; Alexander, B.; \& Fine, J. Traumatic Shock. XV. Carbohydrate Metabolism in Haemorrhagic Shock in the Dog. J. Clin. Invest. 26: 536 (1947).

47. Brewster, W. R.; Isaacs, J. P.; Osgood, P. F.; \& King, T. L. The Hemodynamic and Metabolic Inter-relationship in the Activity of Epinephrine, Norepinephrine, and the Thyroid Hormones. Circulation 13: 1: (1956).

48. Parkhouse, J., \& Simpson, B. R. A Restatement of Anaesthetic Principles. Brit. J. Anaesth. 31: 464 (1959).

49. Popplebaum, H. F. Rediscovery of Air for Anaesthesia in Thoracic Surgery. Proc. Roy. Soc. Med. 59: 188 (1959).

50. French, J. D., Verzeano, M., \& Magoun, H. W. A Neural Basis of the Anesthetic State. Archiv. Neur. \& Psych. 69:519 (1953).

71. Salmoiraghi, G. C., \& Burns, B. Delisle. Localization and Patterns of Discharge of Respiratory Neurones in Brain-stem of Cat. J. Neurophysiol. 23: 2 (1960).

52. Rothballer, A. B. Studies on the Adrenaline-Sensitive Component of the Reticular Activating System. EEG Clin. Néurophysiol. 8: 603 (1956).

53. Price, H. L. Circulating Adrenaline and Noradrenaline During Diethyl Ether Anaesthesia in Man. Clin. Science 16: 377 (1957).

54. Liljestrand, G. The effects of Ethyl Alcohol and Some Related Substances on Baroreceptor and Chemoreceptor Activity. Acta Physiol. Scand. 29: 74 (1953).

55. Woods, E. F.; Richardson, J. A.; Richardoson, A. K.; \& Boztman, R. F., J.R. Plasma Concentrations of Epinephrinen and Arterenot Following the Actions of Various Agents on the Adrenals. J. Pharmacol. \& Exp. Ther. 116.: 351 (1956).

56. Jones, R. E.; Guldmann, N.; Linde, H. W.; DRupps, R. D.; \&.Price, H. L. Cyclopropane Anesthesia. III. Effects of Cyclopropane on Respiration and Circulation in Normal Man. Anesthesiology $21: 380$ (1960). 
57. Habif, D. V.; Papper, E. M.; Fitzpatrick, H. F.; Lowrance, P.; Smythe, C. McC.; \& Bradley, S. F. The Renal and Hepatic Blood Flow, Glomerular Filtration Rate and Urinary Output of Electrolytes during Cyclopropane, Ether, and Thiopental Anaesthesia, Operation and the Immediate Postoperative Period. Suryery S0: 241 (1951).

58. Price, H. L., Conner, E. H., \& Dripps, R. D. Concerning the Increase in Central Venous and Arterial Blood Pressures during Cyclopropane Anaesthesia in Man. Anesthesiology 14:1 (1953).

39. Dripps, R. D. The Immediate Decrease in Blood Pressure Seen at the Conclusion of Cyclopropane Anesthesia. "Cyclopropane Shock." Anesthesiology 8: 15 (1947).

30. Price, H. L.; Lurie, A. A.; Black, G. W.; Sechzer, P. H.; Linde, H. W.; \& Price, M. L. Modification by General Anesthetics (Cyclopropane and Halothane) of Circulatory and Sympathoadrenal Responses to Respiratory Acidosis. Ann. Surg. 152: 1071 (1960). 